\title{
7
}

\section{A bridge across the Middle East The Turkish-Israeli rapprochement}

Two characteristics formerly featuring prominently in Israeli-Turkish relations have vanished from the scene of late. There is now no trace of the "mistress syndrome," the low profile, to revert to the terms of the complaint voiced by Israel's first Prime Minister, David Ben Gurion. ${ }^{1}$ Dr Uri Gordon, the first Israeli Ambassador to Turkey - representation at ambassadorial level, not legation, began in late 1991 - who had started on August 1990 as Chargé d'Affaires in the Israeli Legation in Ankara, and became the first Ambassador on 31 December 1991 wrote:

[I received] a letter from General Halis Burhan, Commander of the Turkish Airforce, inviting the commander of the Israeli Airforce Herzel Bodinger, for an official visit. When the Israeli guest came to pay a call in Ankara on a high member of the Turkish cabinet, he was met there by over twenty representatives of the Turkish press and electronic media. This was no longer "Low Profile." Other similar visits followed. ${ }^{2}$

Neither was there the zero-sum game policy that obliged Turkey to refrain from fostering relations with Israel, for fear of harming its ties with the Arab and communist worlds. The communist bloc is a thing of the past, as is the power of the Arab world to mobilize its resources for the purpose of dictating policy. Turkey may perhaps suffer over its relations with Israel, but in contrast with the past, this no longer inhibits Ankara in developing its contacts with Jerusalem. Israeli-Turkish relations are out in the open now, Ankara flaunts significant portions of this to the public, undeterred by loud criticism or the countermeasures adopted by the Arab and Islamic worlds.

What are the components of these relationships, widely regarded as one of the main crossroads in the Middle East, often said to include the United States, sometimes Jordan, and described in superlatives kept for rare occasions? (For example: "Israel's relations with its second friend [with Turkey; the first is 
Washington] overshadow even its relations with the United States!") The Turkish-Israeli system is called the "Baghdad Pact No. Two," the remarkable tie, the "Phantom Pact," "The Three Musketeers," brilliant move, rapprochement, alliance, alignment, axis, entente, cooperation, partnership, unique development, shock, betrayal, the contemptuous machination of Turkey's rich Jews (the donme), "the odd couple," etc. According to one count, by January 2002 sixtysix authors and research institutions had produced more than 100 academic and journalistic publications that attempted to analyze it. Furthermore, as Anat Lewin noticed, the Turkish press adopted the laudatory tone for Israel - its defense technology is the best in the field, the "Mossad" is the most dreaded counter-terrorism intelligence service, Jewish lobbies on the Capitol Hill are the most effective, etc. - meaning that Turkey has much to gain from befriending such a state. ${ }^{3}$ Conversely, it is worth noting the comment of Ismail Cem, Turkey's Foreign Minister, who complained that deliberate exaggeration is used when his country's relations with Israel are described. Middle Eastern extremist Arabs use excessive terminology, hoping to damage Turkey's influence in the region; Israelis, who fear an improvement in Turkish-Arab relations, do the same, hoping to spoil Turkey's status among the Arabs. "Both our Arab and Israeli counterparts have been warned about the matter," added Cem. ${ }^{4}$

Still, some in Turkey characterize the relations with Israel as the most significant change in their country's foreign policy in the past fifty years. Israeli parallels are the special relationships Israel pursued with France in the 1950s, Iran in the 1960s and 1970s, and South Africa in the 1970s and 1980s. Shimon Peres took a particular pride in the two countries' rapprochement, defining Turkey as the "locomotive force" of the Muslim world and as "the regional super-power." Alternatively, Syria deplores the present collaboration between Turkey and Israel that practically "sandwiched" it, and views it as the greatest mishap the Arab world has endured since 1948 (the loss of Palestine). Al'Quds, a Palestinian newspaper, showed its readers a cartoon of Mesut Yilmaz, Turkey's Prime Minister, dressed with the Israeli flag, and, continued the newspaper, when answering the question what kind of songs he loves, Yilmaz replied: the Israeli anthem $!^{5}$

Israeli-Turkish relations can be divided into two periods. The first comprised some forty years of generally covert links, fluctuating in volume, military and intelligence-orientated in nature; during this period, the overt element featured low-level diplomatic representation, with the civilian dimension as minuscule as mutual commerce. By contrast, we can now point to over a decade of ramified connections - military, economic and civilian - whose rapid expansion, since the early 1990s particularly, never fails to astound. On the Israeli side at least, there exists a great eagerness to foster this relationship to the utmost, along with jitters lest anything beyond Israel's control should bring about its collapse. That is also the undertone behind the words of Alon Liel, an Israeli diplomat who, having served in Turkey during the 1980s, recently called for greater prudence in the special relationship with Turkey, which could be 
destroyed by a rash move on Israel's part. ${ }^{6}$ Looking for an example, Dr Liel could have easily pointed to the unfortunate words of an Israeli official who had specified what Turkey and Israel have in common: "I don't know if you know, but the Turks really hate Arabs very much." Not much longevity awaits the relationship that is founded on hatred. The words of an earlier Israeli emissary to Turkey, who served there in the 1950s, may therefore be equally applicable to the present period:

[T] he only thing that disturbs me is the optimistic tone ... The splendid state of Turkish-Israeli relations is liable to deteriorate for a variety of reasons [of which] the principal one, in my opinion, is not the danger of expanded Arab influence. I shall list the dangers in their order of importance, as follows: (1) The danger of an unsuccessful outcome of Solel-Boneh's projects in Turkey, should such a thing happen, Heaven forbid. (2) Continuation of three-way deals in which Israel makes too great a profit, including the continued re-exportation from Israel of Turkish commodities without Turkish authorisation. ${ }^{8}$

While there is a consensus in Israel as to the value of the special relationship with Turkey - to the degree that Israel's desire for rapprochement with Ankara is taken for granted, hence few analyses are published regarding the necessity of cooperation - in Turkey, by contrast, the issue is controversial, prompting extensive debate. The result is that the Turkish press is quite open and differing as to various aspects of the bilateral cooperation. Certain findings published there never appeared in Israeli sources. For example, Turkey's Aksiyon Magazine is the only organ to publish what is claimed to be the text of the February 1996 Turkish-Israeli agreement on military cooperation. ${ }^{9}$

\section{Israel: cherishing the Turkish connection}

Important changes clearly mark Israeli policies towards Turkey and a clear thread of "Turcification" is discernible in them. For instance, the country apparently departed (May 1997) from the policy prevailing till then in relation to Turkey's conflict with the Kurds, and Prime Minister Benjamin Netanyahu took up position unequivocally on Turkey's side, sharply condemning Kurdish terrorism and ruling out the establishment of an independent Kurdish state. Netanyahu went further, claiming there would be no peace between Israel and Syria unless that country called off its support of terrorism, including that of the PKK. ${ }^{10}$ These words far transcended Israel's actions in relation to the Kurdish issue. Despite Turkish pleas, Israel had declined to take sides against Kurdish terrorism, even while demanding - and eliciting - firm measures by Turkey against Palestinian, Islamic and Hizbullah terrorism. Furthermore, to avoid deviating from the Israeli low-profile line as regards the Kurds, the accords concluded during the November 1994 visit to Israel by Turkey's Prime Minister, Tansu Ciller, relegated mutual anti-terror efforts to the bilateral police agreement, 
alongside the drive against drugs and organized crime. Israel found the Turkish definition of "terrorism" in conjunction with "Kurdish" hard to accept, hence Turkish-Israeli cooperation in this domain was excluded from the agreement on strategic cooperation, relegated instead to the policing dominion. ${ }^{11}$ Israeli apprehensions hinged principally upon fears of vulnerability to a further terrorist front vis-à-vis the PKK. Indeed, the day following Netanyahu's declaration, the PKK announced in Beirut that henceforth Israel - like the United States - would constitute legitimate targets for Kurdish counter-attacks.

But there exists also in Israel a persistent pro-Kurdish sentiment lingering from the country's extensive support for the Kurdish struggle for independence in northern Iraq. (Ariel Sharon, Israeli Foreign Secretary in 1999, said: "It is a known fact that we have good relations with the Kurds in Northern Iraq and especially with Barazani, but we do not have relations with the PKK." $)^{12}$ However, Israel, it seems, did finally acknowledge the Turkish contention that there can be no halfway war against terrorism; Turkey, which acts firmly against antiIsraeli terrorism on its soil, is entitled to Israeli support against the PKK.

Prime Minister Netanyahu, ruling out Israeli-Syrian peace that did not include a Syrian undertaking to halt support for the PKK, likewise conformed with Ankara's views. Turkey displayed growing unease as it observed IsraeliSyrian peace negotiations, including the possibility of Israel lobbying in the United States for Syria's removal from the lists of states that support terrorism or trade in drugs, without Syria relinquishing first its support for the PKK. Turkey was equally perturbed at the prospect that, should a peace treaty be concluded, Israel's demand for redeployment of Syria's army would have it stationing its forces along the Turkish border. Hence, a scaling down of "Israel's Ostpolitik" vis-à-vis the Arab world, Syria in particular, was no cause for regret in Turkey.

It seems also that the Israeli stand in the October 1998 Turkish-Syrian crisis which resulted in the expulsion of Abdullah Ocalan from Damascus and his eventual arrest later on in Nairobi, generally conformed with that of Turkey. When Turkish troops amassed along the border with Syria, Israel announced it would withdraw some of its units from its Syrian front, practically declaring neutrality in the crisis and nullifying the Turkish-Israeli "sandwich" strategy that Syria dreaded. Some in Turkey expressed frustration. ("We weren't surprised: Israel is known as an ungrateful and unreliable entity, always disappointing you when you need them most." Or "Apparently, the Turkey-Israel military rapprochement is important as long as it serves Israeli interests." Or "Israel does not think of anything else but her own interest.") Other sources viewed differently these Israeli moves and regarded them as complementing the Turkish interest, going so far as to confirm that they came as a result of a specific request from Ankara. The Israeli-Turkish "pincer-like strategy," used when an ultimatum was posed to the Syrians, was too alienating and could further exacerbate Turkish-Arab relations. The mood in Ankara was that "while believing that no good will come form the Arabs, we still have to accept that we have to 
live among 100 million of them." For those who looked for a proper occasion, the above crisis furnished an opportunity to demonstrate that a third party - be it the Hellenic world or an Arab state - was never the aim of the Turkish-Israeli rapprochement. ${ }^{13}$

Another event apparently reflecting Israel's growing acceptance of the Turkish view was the decision by the Tel Aviv municipality to bestow honorary citizenship upon Bernard Lewis, a world authority in Islamic and Middle Eastern studies. The literary supplement of the Israeli daily Ha'aretz hosted a wideranging debate among Israeli historians and orientalists as to whether Professor Lewis deserved the honour, and whether or not he had denied that the Armenians suffered genocide during the First World War. A brief survey of Israel's academic community would find that it is still "in" to argue that the Armenian massacre fits the genocide definition. The views of the Israeli orientalist, Yehoshua Porat, are thus exceptional: there is no recall of any equally authoritative pronouncement in Turkey's defense. After categorically rejecting charges of genocide against the Armenians, on the grounds that there is no factual evidence of a high-level Ottoman master plan for their annihilation, Porat adds:

I cannot but express my suspicion - of course unsupported - that there are circles in Israel who find the thrust of Turkish policy hard to swallow. After all, this is a state whose citizens are almost all Muslim, but nevertheless maintains friendly relations with Israel, inclines towards the West, is a member of NATO, and does not share in vilifying the United States as the source of all the afflictions from which the Third World suffers sporadically. I get the impression that Saddam Hussein's Iraq and Hafez al-Assad's Syria get a warmer welcome in those circles, whose criticism of Turkey is highly over-done. ${ }^{14}$

A third conclusion - as yet more of an assessment awaiting confirmation and corroboration - relates to the Israeli-Syrian peace contacts, apparently suspended by Israel for the sake of Ankara. Participants in the occasionally strategic talks held between Israel and Turkey maintain the idea that Israel adopted Turkey's view that Ankara would be harmed by an Israeli-Syrian peace agreement. Such an accord could be expected to enhance Syrian, hence also Kurdish, perhaps even Greek freedom of maneuver for anti-Turkish démarches. It is noteworthy that Turkey made public its agreements with Israel in April 1996, after publication of the existence of a Syrian-Greek military agreement. The Athens-Damascus accords permit Greek airforce planes to undertake training flights over Syrian air space and receive ground services at Syrian airfields, while likewise granting the Greek navy docking and anchorage facilities in Syrian ports. Despite denials by Greece and Syria regarding the very existence of such an agreement, Turkey repeatedly warned Greece against using Syrian air space: in view of Greece's access to practically unlimited air space over the Mediterranean, it has no grounds for training its pilots in Syria and paying dearly for ground services. Such a step would be a provocation, insisted Ankara. At first, Israeli officers and officials maintained that Turkey could take on both Greece 
and Syria "with one hand tied behind its back." Israel Defense Forces Commander in Chief, Lieutenant General Lipkin-Shahak, no doubt not a diplomat, dismissed the dread that Ankara affected concerning Cypriot plans to station Russian-made S-300 surface-to-air missiles on the island, by remarking that "Turkey could annihilate Cyprus with its fishing fleet." ${ }^{15}$ Yet, following their meetings with their Turkish counterparts, Israeli negotiators apparently grasped the depth of the Turkish feeling on the Greco-Syrian issue. This might support the view that suspension of Israeli-Syrian contacts was designed inter alia to placate Ankara. As already noted, the topic deserves further consideration; if established, it would reflect the degree of "Turkification" Israel is experiencing.

The most vivid illustration may be offered by Israel's self-control and restraint in the following instance. As a rule, any challenge to the Second World War Jewish Holocaust and its virtually sacrosanct status comes in for unequivocal Israeli condemnation, going as far as total rejection and censure. But in this case, Israel showed self-restraint. In January 1997, members of the Turkish parliament, headed by their speaker, Mustaffa Kalemli, visited Yad Vashem in Jerusalem, the national shrine commemorating the Jews massacred in the Second World War. Two of the group were members of the Rafah Partisi (Welfare Party); one of the two, Ahmed Derin, concluded his visit to the shrine with the hope that no institution like Yad Vashem would ever have to be erected again in commemoration of anyone, the Palestinian people included.$^{16}$ The restraint that Israel displayed can of course be ascribed to self-interest and profit-and-loss calculations. But it can also be attributed to the growing Israeli awareness that Turkey's frame of reference, which also embraces the Arab and Islamic dimension, does not always correspond with that of Israel, and Israel therefore cannot expect exclusivity in its relationship with Turkey. Turkey has close ties - in commerce and energy - with Iran. Should Iraq be freed of current sanctions, Turkey will become its main supplier. Syrian-Turkish relations have greatly improved recently, and after a lengthy period without an accredited Turkish ambassador, Damascus has consented to the nomination of a new ambassador. ${ }^{17}$ The Israel-Turkey rapprochement is thus just one thread in a thick web of Turkish interests. Furthermore, while Israel endeavors to play down Turkish sensitivities over GrecoIsraeli relations (and Ankara's effective veto of elements thereof - see later), Israel must come to terms with Turkey's other spheres of interest.

Turkey has its own shock-absorbers in relation to Israel: when the Refah Partisi was declared illegal in January 1998, the Speaker of the Knesset, the Israeli parliament, told a group of foreign military attachés - including the Turkish representative - that "Till yesterday, I thought there are two democracies in the Middle East. Since yesterday, I'm not so sure, after what happened in Turkey." The Speaker subsequently withdrew his remarks, praising the robust nature of Turkish democracy, whereupon the incident was written off. ${ }^{18}$

A significant change - and for the first time ever in the three-way relationship between Israel, Greece and Turkey, an overt one - came with Israel's refusal to expand its military cooperation with Greece. For readily comprehensible 
reasons, Greece exhibits great interest in the burgeoning military contacts between Israel and Turkey. Three Greek military attachés are stationed in Tel Aviv; the Israeli military attaché in Rome is also accredited to Athens. In view of Greece's intention of spending 16 billion dollars in the decade to come on procurement of equipment and weaponry and modernization of its army, Israeli arms manufacturers might have been expected to display an interest. ${ }^{19}$ However, regardless of Greek requests, Israel's aircraft industry has not taken up the tender for upgrading and modernizing forty Greek airforce F-4 (Phantoms). Likewise, Israel has restricted military exports to Greece to harmless items like bullet-proof jackets, patrol boats without armament, detachable fuel tanks for aircrafts, etc.

Arms sales to Cyprus are exhibited as an illustration of the policy of SIBAT, the body responsible for Israel's military exports. As Israeli arms exports to the conflict-ridden island are liable to be harmful to a country friendly to Israel, SIBAT limits the quality and extent of Israeli arms sales to Cyprus to "non-lethal weaponry." We should recall that an Israeli-Greek military cooperation agreement (similar to the one signed later between Ankara and Israel) was concluded as far back as December 1994. Israel, however, avoided imbuing the agreement with any real substance. Greece, too, recently called off joint naval exercises, on the grounds - or more plausibly, the pretext - that its navy was too busy intercepting infiltration from Albania and could not spare a single frigate for joint exercises with the Israeli navy. ${ }^{20}$ The change in Israeli policy towards Greece is expressed less in the refusal to sell that country this or that item of military hardware, than in public abandonment of the forty-five year old policy of (ostensible) neutrality in Greco-Turkish relations. During the years 1950-90, Israel went so far as to claim that the doleful state of its relations with Greece was due to that country's capitulation to Arab pressure. The 1990s, however, exposed relations between Jerusalem and Athens in a further respect, when Israeli companies declined to take up tenders in Greece lest it be interpreted as detrimental to Turkish interests. Disagreements were reported between the Israeli defense establishment, anxious to avoid fostering relations with Greece for fear of endangering links with Turkey, and the foreign ministry that sought to preserve a balance within the Greco-Turkish-Israeli triangle. Interestingly, the division is different in Greece, where the military establishment is keen for links with Israel, while the foreign ministry is traditionally hostile.

Israel has recently been exposed to two symptoms of Turkish sensitivity. The Israeli-Palestinian conflict threatened to push the Turkish-Israeli relations backwards, in particular when Ankara hopes to lessen the Arab world's animosity pertaining to her relations with Israel, by openly supporting the Palestinians. Often Ankara differentiates between Israel and Zionism, and openly declares that. ${ }^{21}$ Apparently, Turkey feels a responsibility for the plight that befell the Palestinians: the Ottomans were the first to permit, during the nineteenth century, the immigration of Zionism-inspired Jewish colonists to Palestine thus starting the conflict there. "We share something in common with the Palestinians," say 
Turkish officials, "We were both duped by the Arabs, who stabbed us both in the back, causing us to lose the Empire, and left the Palestinians alone to their fate." All through the 1990s the Turkish media clearly sided with the Palestinian version of the peace negotiations with Israel, having only minor reservations pertaining to the integrity and talents of the Palestinian leadership. Intermittently, Turkish reporters gave deeper analyses, in addition to almost daily reporting, of the Palestinian-Israeli conflict. The general picture - who is to be blamed and for what - has not altered:

The Children of Israel have given the first monotheistic religion to humanity but in the meantime committed their first sin. Yehuda has spread the seeds of racism onto the world. He has said, "You Children of Israel are different from all other tribes." This is how the Jews have committed their first sin. Then they got the blood of Jesus on their hands. And they slowly paid for these sins for 2000 years. Russians have slaughtered tens of thousands of them in every pogrom, the Spaniards were unable to extinguish [all] the Sepharadim [Jews of Oriental origin] by killing them. The remaining [Jews who were spared the killing were expelled from Spain in 1492] sought refuge in the arms of the Ottomans. What happened to the Ashkenazim [Jews of European origin] was not very different. The grandchildren of the Children of Israel, alias the chosen people of Yehuda, paid for being chosen by inhaling Zyklon $B$ gas during World War II ... The Jews who have paid for their sins for thousands of years are making their relatives pay for it in the 20th century. The West gave them Palestine, the land of their Semite relatives, as a present [with the result that] there has been much bloodshed in the Holy Land since the proclamation of the State of Israel. ${ }^{22}$

According to the Turkish media the Palestinians paid a dear price because the powers - the same Christian West that had plotted against Turkey - conspired against them. The Arab side who almost took control over Palestine during the war of 1948, was forced to give in to American and Soviet pressure. As from July 1948, American and Soviet troops were deployed on Israeli soil, thus putting into effect the plan of giving the Jews a state. At the entrance of the Knesset, there is a slogan, "Israel's borders are from the Nile to the Euphrates." The reporter told his readers that a map of this kind is in Israeli school books, "planting imperialist ideas in the minds of children." The Middle East, Iran, Pakistan, the Gulf, Africa and, of course, Turkey, are on Israel's expansionist list. ${ }^{23}$

Jewish settlements - according to Radikal "a knife in the chest of the Palestinians" - is the strategy used by Israel to apply this expansion and establish legitimacy in the land: "Seasonal families stay at one settlement for three months and then move to another one. This is how the policy of creating legitimacy on land works." ${ }^{24}$ Radikal knew to say that in accordance with their rabbis' orders, the settlers kill Palestinians. In case you are wounded or in need of help, a settler will not come to your assistance if you are not Jewish. In fact he will find a way to kill you. ${ }^{25}$ What is left for the Palestinians is to defend themselves by acquiring martial arts, karate for instance. However, this enables them to confront the Israelis solely by using their bodies. Had "Bibi" (Benjamin Netanyahu) 
been a Palestinian, his right of residence in Jerusalem would be abrogated: a Palestinian, native of Jerusalem, who leaves the city for more than seven years is not entitled anymore to an Israeli identity card ("Blue Card"). Had Netanyahu, who lived and worked in the United States for twelve years, been a Palestinian, he would have been banned from returning to the city. ${ }^{26}$

The words of Zvi Elpeleg, Israel's ambassador to Ankara (1995-97), are worthy of attention. Elpeleg stressed Turkish sensitivity to the Palestinian issue. In his view, a crisis in Israeli-Arab relations would not entail deterioration in Israeli-Turkish ties, but a downturn in relation to the Palestinians would. "Their sensitivity on that point is almost as great as on the Armenian issue," Elpeleg warned. "Many millions in Turkey are interested in nothing outside their own borders more than the Palestinian issue; no government in Turkey can withstand the pressure of those millions." ${ }^{27}$ By way of illustration: Turkish journalists smuggled used gas grenades, cartridges and bullets into the chamber of the Israeli Prime Minister to protest against their use by Israeli troops while confronting Palestinians. ("Try to do this in Cankaya Palace in Ankara," said a Turkish officer) ${ }^{28}$ Similarly, it is to be doubted whether Israelis have ever heard the foreign minister of a friendly country says anything to match the following dialogue. In response to a question from the Cumhuriyet, the Turkish Foreign Minister at the time, Mumtaz Soysal, explained what he meant by "activities defined as terror by Israel." It should be recalled that he was speaking in the year following the Oslo accords, and despite of the spate of terrorist suicide bombings then sweeping Israel:

Question: With the phrase "defined as terrorist": do you mean to say that they actually are not so?

Answer: Yes. Because not everything is "terrorism." The struggle of Palestine still continues. Palestine has not achieved its wishes completely. Neither have the Palestinians... Among them are those who want to continue struggle by defending their rights, they are trying to defend their rights. But a part of the Israeli people is insistent on stamping these efforts as "terrorism." ${ }^{29}$

Ankara insists that there is no resemblance between the Kurdish struggle for self-determination and the Palestinian one, nor any similarity between the two leaders, Ocalan and Arafat. Turks resent any comparisons ("ridiculous analogy," "funny semblance") between the occupation of the northern part of Cyprus and the Israeli one in the West Bank and the Gaza Strip. They see, however, the attraction, particularly in Europe, in portraying the Palestinians and the Kurds as parallel cases. Warnings, comparisons and lessons, therefore, were quick to be voiced. When Ocalan (“Apo," i.e. uncle), was facing expulsion from Damascus, as Ankara had insisted, the risks for Turkey were predicted, in particular when the Arafat precedent was quoted:

Unfit for Arafatization (Arafat Lastiramamak)

Realistic evaluation of the efforts for the Arafatization of Abdullah Ocalan:

Efforts to try and build a parallel between the lives of Apo and Arafat are in vain. Apo was born within the borders of the Turkish Republic, he is from Urfa. Arafat 
was born in Cairo, not in Palestine. His father was of Palestinian origin but lived in the rich quarter of Heliopolis in Cairo. He had sold all his land in Palestine to achieve his ambitions in Egypt. Yassir Arafat has always blamed his father for not leaving him a piece of land in Palestine, but to the outside world he acts as if his father's land has been occupied by Israel. Abdullah Ocalan never had a problem such as not having land, occupation and exile.

Arafat speaks Arabic with Egyptian accent, not Palestinian one. Apo, on the other hand, did not know Kurdish when I met him in 1991. In our interview at the Beka'a he told me that he speaks Turkish, gives orders in Turkish, and thinks in Turkish. Arafat went to univeristy in Cairo, Ocalan attended the Faculty of Political Science in Ankara.

Arafat had behind him the oil sheikhs, kings and dictators ... This was the force from which Arafat got his strength. He was accepted to the U.N. General Assembly with the votes of the Muslim and Arab nations. Terror was still new and it could be accepted as a struggle of the Palestinians [who were] trying to get back [their] occupied land.

Ocalan does not have all that money and power behind him and terror is now considered a global threat. Still, Turkey should be very careful and should not forget that Arafat started gaining his real power after he was out of Syrian control, and he managed to harm relations between Israel and her neighbours, especially Egypt, by opening representative offices in those countries. ${ }^{30}$

Another comparison was made between the Jewish Holocaust and the Armenian claim to have suffered genocide during the First World War. The nine-month prison sentence given to the French Roje Garaudy for questioning the number of Jews killed during the war (according to Garaudy 1.5 million instead of 6 million Jews), raised doubts as to the "intolerance about figures" that a country like France suffers from. Garaudy, according to Zaman, "only claims that the figures have been intentionally exaggerated, and unacceptable policies have been built upon these figures." Is this claim not worth investigating, asks Zaman? It concludes that "even in Europe academicians are not allowed to investigate and make declarations outside the official view." The comparison with "the incidents of 1915" is clear: "There is a big imbalance between the number of Armenians claimed to have been killed and their actual population. This shows that those who have exaggerated the figures had some other intentions." 31

The nomination of Ehud Toledano as the Israeli ambassador to Ankara, and the furious response it evoked in Turkey - he was ultimately turned down by Turkey - confronted Israel with the second Turkish sensitivity, this time over accusations of genocide of the Armenians during the First World War. It was falsely - reported that in a radio program in 1981 Professor Toledano had allegedly accused Turkey of massacring the Armenian people. The terms and expressions the Turkish press employed in relation to Toledano were inflammatory in the extreme - "Toledano [is] an extreme pro-Jewish Sharia" - in contrast with the outgoing ambassador, Zvi Elpeleg, known to be a secular Israeli. "Toledano is an admirer of the Armenians and even quarrelled with [his Professor] Bernard Lewis for this reason." And so on. ${ }^{32}$ It appears to have been beyond 
Toledano's power to overcome the rejection of his appointment to ambassador in Ankara, in view of the multitude of interests that stood to lose thereby. Ali Birnad was right on target with his article in Sabah, attributing the scuttling of the Toledano nomination inter alia to the "jealousy of his [university] colleagues." ${ }^{33}$ Israel and the Israelis are probably far more attentive now to Turkish sensitivities on the Armenian issue. With that, the following quotation is worthy of attention - despite its length and the excessive fantasy to which Toledano was linked. It ties together Turkey's greatness, Armenia, Russia, the Armenian lobby in the United States, Azerbaijan, Israel, Bernard Lewis, Professor Toledano's colleagues at Tel Aviv University, and Benjamin Netanyahu's falling-out with his Foreign Minister David Levy:

Ambassador Toledano is said to be the student of Prof. Bernard Lewis, a well known American historian of Jewish origin, known for his pro-Turkish stand. Toledano, whose pro-Armenian stand and articles on Armenian genocide claims against Turkey have come to light, went so far as to quarrel with Lewis on this issue, and other scholars at Tel Aviv University report that the two professors are not on speaking terms for this reason.

In [a] magazine published in Israel, it was stated that Turkish-Israeli relations might be endangered due to this position of Toledano.

That's not all. It's also stated that Toledano distorted the facts, adopting a position more pro-Armenian than an Armenian, with articles claiming that the Turks conducted a genocide against the Armenians.

It was learned that the appointment of a man known for his clearcut identity in Israel and known to be supported by the Armenian lobby in the USA, is causing concern in the Netanyahu wing of the Israeli government; but [David] Levy, being a member of a coalition party, objected to the bid to withdraw his nomination. It is also claimed that Toledano, not being a professional diplomat, will harm the relations unfolding between Israel and Azerbaijan after Netanyahu's visit to Baku. The Armenian lobby and Armenian-Russian alliance will thus have an important opportunity to torpedo Turkish-Azerbaijani-Israeli relations.

In view of all these developments, we can only say that, hopefully, the ambassador's biased approaches and view have been changed. We hope he has come to grasp the greatness of the Turkish nation and its fairness, and the unfair treatment it has endured. We hope he has achieved a perception of historical facts and reconsidered the position of his own country.

It's not easy to perform duties in Ankara which will be one of the most conspicuous centres of the 21 st century. For this reason the eyes of the Turkish nation will be fixed on Toledano. ${ }^{34}$

It should be noted that Israel was aiding Azerbaijan to set aside US Congressional Amendment 907, adopted during the Armenian-Azerbaijani conflict over Nagorno-Karabakh. Passed under pressure from the Armenian lobby in the United States, the amendment precluded US aid to Azerbaijan. Unlike reservations in Congress, the Administration in Washington has been eager to aid Azerbaijan, which borders on Iran and grants American companies oil and gas prospecting concessions. ${ }^{35}$ 
The Armenian issue did damage the bilateral relations; concurrently, the same Armenian issue proved how solid the relations are. In April 2000 the Israeli Minister for Education, Yossi Sarid, participated in the commemoration gathering held in Jerusalem, in memory of the Armenian victims of the First World War. Sarid announced that from now on Israeli high-school syllabi will include the 1915 plight of the Armenians in the Ottoman Empire. Turkey reacted by officially boycotting the Israeli Independence Day reception held in Ankara a fortnight later. It also raised the possibility - of course, reassured his audience the Turkish Ambassador to Israel, nothing practical, only a theoretical possibility - that Turkey's Secretary for Education would include the issue of the Jewish Holocaust denial in Turkish schools' syllabi. ${ }^{36}$ Both sides attempted to confine the event to verbal or ceremonial reactions. The Foreign Office in Jerusalem announced the Israeli official stand on the issue: "We accept that many Armenians perished in the wars that marked the end of the Ottoman Empire. We sympathise with the victims of these events. These events that brought so much suffering to the Armenian people should not be forgotten." The Israeli daily $H a^{\prime}$ aretz commented that with minor alterations this same official stand could be used to express condolences on the death of Americans in the recent influenza epidemic. ${ }^{37}$ An Israeli official in Jerusalem explained:

We are in a deep problem. Like others who enjoy good relations with Turkey, we find ourselves between the hammer and the anvil. One small slip of a tongue and immediately you face a federal case ... It is extremely painful for us because our Holocaust is recognised by the world. Each time when you talk about the Armenian issue you have to think twice how on earth you should call "this thing." Turkey takes issue with whoever talks about the "Armenian genocide." So our position is that we recognise the plight of the Armenians, but we do our utmost to evade historical circumstances and the question of who is to be blamed. ${ }^{38}$

Bitter conflicting views did come to light in Israel following the above. We have already quoted Yehoshua Porat. Shimon Peres referred to the Armenian plight as "tragedy, not genocide." Tom Segev, a well-known publicist in Ha'aretz, mentioned another aspect: the Armenian case was not included in the curriculum of Israeli schools because granting it a recognition, "might pose a competition before the Jewish genocide. The Israeli culture of commemoration does not accept that genocide could be a universal phenomenon. It presents the Jewish extermination as a unique phenomenon." ${ }^{39} \mathrm{Ha}^{\prime}$ aretz's editorial was even harsher: it blamed Israeli diplomacy for deliberately acting to forget the past of another people. This is a problematic stand, warns the newspaper, in particular in light of the Jewish struggle against Holocaust denial. It weakens the moral stand of this fight, said Ha'aretz:

The Jewish people, a victim of the Holocaust, must remember the genocide of another people. No diplomacy should stand in the way of it. It is wrong to assume that there is an insoluble contradiction between political interests and a moral stand. The problem is not Turkish pressures. The problem is to give up to them. ${ }^{40}$ 
Palestinians and Armenians aside, and one easily discerns that the Israeli society highly interests the Turks, in fact on certain occasions attracts and fascinates them. "When you are in Israel, all your problems are solved the moment you show a Turkish passport!" is but one of the enthusiastic descriptions. ${ }^{41}$ Many aspects prevailing among the Israelis have become the subjects of inspection by Turkish newspapers. Indeed, few of them have appointed permanent correspondents who report from Jerusalem and Tel Aviv. ${ }^{42}$ For instance, about the conflict between orthodox and secular Jews: secular shop-owners in Jerusalem found a way to bypass the Jewish orthodox ban to work on the Sabbath by selling their shops to Muslims for one Israeli shekel on Friday and buying them back on Sunday morning. There are similar stories about the Batsheva Ballet Dance Group that was forced to wear modest attire in accordance with religious regulations; the division between men and women in Jewish Hassidic dancing; the difficulties and homesickness of the newcomers to Israel; the Viagra sales boom in Israel; the ban on playing music of the much loved by the Nazis composer Richard Wagner; the fashion show of Israeli bathing suits that carried Egyptian designs ("[Israeli-Arab] Peace on the Podium"); the television commercial about a detergent that could clean even Monica Lewinski's dress; the high-quality politicians $[$ sic] that the Israeli coalition government system attracts; and so on. ${ }^{43}$ Israel is described as "Little America;" in certain areas it surpasses America. True, you won't find car industry in Israel but you do have the IAI, Israel Aircraft Industry that produces sophisticated technologies and aircraft. And also: "I took a bus from Jerusalem to Tel Aviv . . . Where are we? If this is still the same desert we have been travelling on since Baghdad, then what is this pasture all around me? This is a heaven created on the desert. The journalist in me wants to send out praises to those who have fought the desert with determination and who have won." ${ }^{44}$

The Turkish media attributed one simple reason to all these successes: it is not foreign money that makes the miracle but the high priority and financial assistance given to education, research and development, and industrialization. ${ }^{45}$ Israeli freedom of expression fascinates the Turkish correspondents: the television often criticizes the government and could say anything about Netanyahu, could call him a liar, crook, etc., and you will not be prosecuted. Try - if you are brave enough - to do the same to Arafat, Mubarak, King Hussein, Assad: you will immediately be jailed, in fact your life will then be in peril. And the lesson as the Milliyet sees it: when the Arabs cherish freedom of speech, they will be able to regain their rights. ${ }^{46}$

Occasionally, however, the above superlatives and their like are balanced by calls for more realistic interpretations for the "Little America" phenomenon. The country is described as the product of the money of rich American Jews, which means that at its fiftieth anniversary (1998) Israel is still an artificial state, heavily dependent on external support. Also, "What a pity" it was to establish the state of Israel: it resulted from the guilt-conscience of the Europeans who had committed the Holocaust plus the hypocrisy of British colonialism, US 
interests ,and the strong Jewish lobby therein. All made the country built upon a lie, namely: the portrayal of Palestine as an empty place where you could "Give the land without people to the people without a land." ${ }^{47}$ Zaman's Taha Kivanc recorded the following in his "Notes from Jerusalem":

Our businessmen who found many things to criticize in Amman in relation to the city and the people, were a bit hasty in admiring everything they saw in Israel. Their eye caught the richness and high technology used everywhere in Israel. This is always very effective in impressing people. However, the businessmen did not even care to listen to words such as, "These people have immigrated to Israel already mastering knowledge and know-how. Half of Israel's national income is US financial aid." I think, however, that there are two important achievements in Israel: one is that they have turned the desert green, and the other is that they have revived a dead language and are using it as an everyday language. Everything besides these two things can be bought by money or achieved by well-educated people. ${ }^{48}$

Admiration for the other is, many a time, not restricted to one side. Not surprising, therefore, that Israelis often envy the way things are determined and done in Turkey, economy exclusive. "We should talk Turkish to the Palestinians/ Hizbullah/Syria/Iraq/Iran," is the prevalent advice offered in Israeli media, in particular following the Syrian yielding as regards the presence of Abdullah Ocalan in Damascus and the victory of the Turks over the PKK. Turkey's credit among the Israelis jumped sky-high when its F-15s forced an Iranian aircraft on its way to Damascus to land in Dyarbakir. There its cargo was searched for weapons that Tehran might have shipped to the Lebanese Hizbullah. Israel has also to learn from Turkey how to impose secularism or how to give the coup de grace to the old theocratic order, the same as Mustafa Kemal did, by abolishing the wearing of the fez in 1925. (Israel needs an authoritative, secularly courageous leader like Ataturk, insisted the writer). And, unlike the Israeli political system, the writer called to learn from Turkey how to eliminate the influence of army Generals by not appointing them to political posts. ("Aren't there anymore civilians in Israel that we choose our leaders from among the Generals?" asked an admirer of the Turkish system). And so on. A selection of the titles of the articles that praise Turkey read: “Talk to Him in Turkish," "Take Turkey, For Example," etc. ${ }^{49}$

Turkish authoritative assertiveness does attract the Israelis. Still, the following quotation shows another kind of appreciation for the Turkish way. Note, for instance, the plans to change massively the Yitzhak Rabin Suqare in Tel Aviv, the place where the Israeli Prime Minister was murdered, and to turn parts of it into a huge parking lot. "The largest public square in Tel-Aviv is being sacrificed ... but without a public square we are not a public," declared the writer. However, there exists a remedy, and not so far from Tel Aviv:

Recently I returned from Turkey our neighbour. There, they were wondering how to commemorate one of the most unnecessary battles in human history: the battle of Galipoli ... After 85 years all the parties to the battle looked for a proper way to remember it, and decided on an international competition on how to re-plan the 
place. The great surprise was that the plan that won the contest was the one which strongly recommended neither to change nor to touch the site. His Excellency the City Engineer of Tel-Aviv: you should not go so far, to Paris for instance, to learn about squares, or to learn about the culture of designing public places, or how to deal with a national/international commemoration of a site which is a fixed part in the collective memory of the nation and of the world. Suffice it to stop at the neighboring country. You will then be enlightened..$^{50}$

\section{Turkey: policies and attitudes towards Israel}

The disintegration of the Soviet Union and termination of the cold war have inspired changes in the roles of Israel and Turkey. Both prominent cold war players since the late 1940s, the two countries have been cast into a fixed role with the West, a state of affairs apparently immutable. The collapse of communism put this role in question (more evident in Turkey than in Israel) in both countries, neither being located geographically in the West or Europe, even if their leaders would have wished it otherwise. Likewise, the Ostpolitik pursued by each of the two governments - that of Necmettin Erbakan, whose Muslim visions rendered him less than eager for an extended honeymoon with Israel, and Israel's pursuit of a "New Middle East" (overwhelmingly identified with Israel's Labour Party Nobel Prize Laureate Shimon Peres) - served as catalysts in the Israeli-Turkish rapprochement. When Turkey's pro-Western secular military establishment felt threatened by Erbakan's Islamic policies, it stepped up the pressure in the opposing direction, generating a steadily expanding interaction with Israel. Similarly, when the May 1996 newly installed right-wing Netanyahu government in Israel suspended contacts with Syria - thereby meeting Turkish expectations - it was precisely at this point in the premierships of Erbakan and Netanyahu that relations between their two countries scaled to heights previously unknown. Bowing to military demands, Erbakan and the seventeen Refah Partisi ministers of his cabinet endorsed the contract for the upgrading in Israel of Turkish F-4 aircraft. The quid pro quo: consent of the Turkish military to a limited reduction in the size and activity of the multilateral force - actually Anglo-American units (known as Operation Provide Comfort or as Operation Northern Watch), that monitor from Turkey the northern regions of Iraq, north of the thirty-sixth parallel.

The sentiments portrayed here were best depicted by Ilhan Selcuk, a left-wing Turkish intellectual not renowned for his pro-Israel sympathies. A summary of his words in Cumhuriyet interprets the Israeli-Turkish rapprochement. According to Selcuk, Saudi Arabia and Iran, their mutual rivalry notwithstanding, share the view of secular Kemalist Turkey as a threat. Even if they detest one another, all the "pro-shari'a" groups, are the enemies of Turkey. All the Muslim states would sense triumph should secular-Kemalist Turkey collapsed. Moreover, the Refah Partisi is a Trojan horse playing along with these forces hostile to Turkey. Selcuk 
goes on to list Turkey's enemies who supported the PKK: Armenia; Greece; Syria; the Cypriot Greeks; Iran; and the Greek and Armenian lobbies in the United States. According to Selcuk, that leaves Turkey with nobody but the Jewish lobby and Israel, and all that is asked of Israel is to discharge its obligations to the Palestinians. Selcuk concludes accordingly that, with Turkey encircled by the hostility generated by cooperation between shari' $a$ and Orthodoxy, "it is a vital Turkish national interest to cooperate with Israel." Israel relieves Turkey's isolation imposed by this wall of hostility, simultaneously fielding a Jewish American lobby to counter-balance the Greek and Armenian lobbies. ${ }^{51}$

Ambassador Zvi Elpeleg explained Turkey's interest in Israel: it is helpful that the Turks believe in the Protocols of the Elders of Zion, and deduce therefrom that Israel is capable of swaying the whole world..$^{52}$ The Turkish press often describes Israel, in particular the James Bond like operations of the Mossad, as capable of furnishing Turkey with intelligence and services beyond any imagination. ${ }^{53}$ Turkey notes the different standards applied towards Israel. For example, German police treated leniently the shooting by Israeli security at Kurds who stormed (February 1999) the Israeli consulate in Berlin in the aftermath of the kidnapping of Abdullah Ocalan: notwithstanding Israel's vehement denials, its was widely assumed that the Mossad assisted Turkey in locating the PKK leader. If it was Turkish security, Germany's reaction would have been totally different, complained the Turkish the press. In a similar event in Berne some years ago, the Turkish ambassador to Switzerland had been declared persona non grata. ${ }^{54}$ The conclusion: let us befriend the Israelis.

In fact, Israel and its subsidiaries do undertake ramified lobbying efforts on Turkey's behalf. Shimon Peres's intervention with his colleagues in the Council of Europe, the European Parliament and the Socialist International, convinced many of them to shelve their objections to the customs union that the EU concluded with Turkey early in 1996. Israel has acted similarly on Turkey's behalf in the United States, particularly in toning down congressional criticism of Turkey over its treatment of the Kurds, human rights, rights of political association and freedom of speech, imprisonment of journalists, restrictions on free press, etc. The American Jewish Committee (AJC) and B'nai B'rith are the forefront of acting on behalf of Turkey in the United States however, often at a cost - the anger and distaste of other ethnic groups, especially the Armenian and Greek Americans, and criticism in the American public opinion. "I can not stress enough that for Americans, a free press - that is the freedom to express contrary views in print - is absolutely fundamental to our definition of a functioning democracy," stated the representative of the AJC to his Turkish audience in Istanbul. "I am selfish," he added: improvements in the above fields would deprive hostile lobbies of ammunition and help winning the battles on the Capitol Hill on Turkey's favour. ${ }^{55}$ Russian Foreign Minister Yevgeny Primakov has also protested over Israel supporting the Turkish campaign against the stationing of S-300 missiles on Cyprus. ${ }^{56}$ In all, Israeli efforts have achieved a mixed success: the US Administration is interested in closer ties with Turkey, but 
Congress remains critical. The alternative seemed obvious as the Radikal analyzed it: "Turkey is in search of a country to buy arms without being confronted with the human-rights, Kurdish and Cyprus issues, and Israel needs a country to sell its arms to." ${ }^{57}$

Similarly disappointing was the flat rejection the EU handed out to Turkey in Luxembourg, in December 1997, and the ensuing fallout in the EU-Ankara relations. Turkish Airlines' renewal of its fleet of a 2.5 billion dollar budget went for forty-nine Boeing 737-800 airliners, granting the US manufacturer preference over its European Airbus competitors. While Prime Minister Rabin and Secretary Peres found it relatively easy to promote the Turkey of President Ozal and of Prime Minister Ciller, the succeeding Israeli Prime Minister, Benjamin Netanyahu - himself not exactly persona grata in the West (he complained that the American press portrayed him as "A Western Saddam Hussein") - certainly had it much harder to intervene on behalf of Turkey's Muslim Prime Minister, Necmettin Erbakan. ${ }^{58}$

The Israeli-Turkish rapprochement was a further episode in the domestic stand-off, setting Turkey's Western, secular, military establishment at loggerheads with the religious parties and organizations. It looks as if Turkey's secular military establishment dictated a public policy of rapprochement with Israel, in spite of domestic Muslim opposition, sometimes disregarding complaints over the flouting of proper democratic procedures in implementing ties with Israel, and regardless of Refah's traditional anti-Israel and anti-Semitic positions (more of which later). ${ }^{59}$ Turkey's Islamic press linked efforts to close down the Imam schools (Imam Hatip Lycee) to the collaboration between Turkish Generals and Israel. ${ }^{60}$ Particular indignation was directed against General Cevik Bir, Turkey's Deputy Commander-in-Chief, who was portrayed as tough and extremely anti-religious. It should be recalled that Bir is the Turkish signatory on the military cooperation accords with Israel.

Domestic Turkish differences may also be linked to the events that erupted early in February 1997 in the Ankara suburb of Sincan, a working-class town, 25 miles from Ankara. "Jerusalem Day" was marked there by anti-Israel protests, with stone-throwing at actors depicting Israeli soldiers, the burning of the Israeli flag, and a vigorously anti-Israel speech - also calling for adoption of the Muslim shari'a as Turkey's future law - from the Iranian ambassador Raza Bageri. The latter cursed and reviled the United States, and promised Sadat's fate would befall anyone signing agreements with Israel. The reaction of the Turkish army was exceptionally forceful. The following day, tanks, personnel carriers and other military vehicles churned up the streets of Sincan. A military spokesman denied any connection between the military movements and the Muslim rally. ("We held routine maneuvres. That is the normal route the tanks take. Are they supposed to hover over the neighborhood?”). Sincan mayor, Bekir Yildiz, of the Refah Partisi, was dismissed from his post on the orders of the Interior Minister. Indicted with others on charges of disrupting public order, aiding an armed gang, and disseminating religious hatred, he was sentenced to four 
years and seven months' imprisonment. The Iranian ambassador was declared persona non grata, whereupon Iran expelled the Turkish ambassador and another diplomat. (In September 1997 the two ambassadors returned to their respective posts). ${ }^{61}$

A further expression of Islamic protest was the attempt on 19 May 1996 to assassinate President Demirel in the west Turkish city of Izmit. The would-be assassin justified his act as a response to the conclusion of the military agreement with Israel. In addition, the Muslim press knew to tell about the Israeli ambassador's excessive involvement in Turkey's domestic affairs, serving as the "confidant" of the Generals in plotting the toppling of Erbakan's government. ${ }^{2}$

\section{Refah and Israel}

Of special interest is the domestic Turkish response - by the Refah party primarily - to relations with Israel. We have already noted that bilateral relations flourished - contrary to Refah's declared wishes - particularly during Necmettin Erbakan's term as Prime Minister. This calls for a more detailed explanation.

The Refah and its leaders adopted intransigent positions vis-à-vis Israel, notably so prior to Erbakan's elevation to Prime Minister, but it was also evident during his incumbency. Islamic organs depicted Israel as "abnormal" by comparison with existing states. Not merely the state of its inhabitants, Israel is also the state of all Jews, every Jew in the world has the right to settle there, yet it possesses neither constitution nor recognized boundaries. ${ }^{63}$ Israel's creed, Judaism, was described as a fundamentally political religion, actually the most political of all faiths. Its aim is to expand from the Nile to the Euphrates, actually to Nevsehir in Kapadokia and to Sanliurfa in the southeast of Turkey: the two blue stripes in the Israeli flag symbolize the Tigris and the Euphrates. Israel, thus, is a double enemy of Turkey: she harbours expansionist dreams pertaining to her territory, and supports the establishment of a Kurdish state, clearly contrary to Turkey's interests. The leadership of the Fazilet party - successor to the Refah - termed Israel as a "questionable country of three million," which means that for a huge country like Turkey to look to Israel for guidance in its foreign policy, "is not only a historical mistake but an international scandal." Furthermore, a Turkish newspaper explained that the Refah had to close down, eventually to be succeeded by the Fazilet, to get rid of the "Zionist and Jewish domination" among its high echelons, in particular to purify itself of the corrupting influence of the powerful Turkish Jewish community. ${ }^{64}$

Anyone concluding an agreement with Israel must be on constant alert, said the Refah, for Jews love no one but themselves. Anyone in close contact with Jews is never content, as experience has shown over the generations. ${ }^{65}$ Israel also foments dissension between Turkey and its neighbours: even though Turkey and Iran have had no border conflict for centuries, Israel was inciting Turkey against Iran, or revealing the close military secrets of Turkey's neighbours (for example: 
Turkey was provided with the secrets of the Syrian MIG-29). ${ }^{66}$ Furthermore, at cocktail parties the Israeli embassy holds, alcohol is consumed like water and toasts are drunk "to honour the massacre of Muslims. Every imaginable evil occurred at these Independence Day parties." ${ }^{67}$ But Turkey is not alone: Israel had become the problem of the entire Muslim world, for its establishment had shunted the Jewish problem from Europe to Asia, from the Christian world to the Muslim sphere. As far as Muslim Turkey is concerned the danger is double: the Greek Orthodox Patriarchate in Istanbul pursues the same plans as the Jews have in the past. The latter waited for 2000 years to establish a state, finally realized it by buying land during the time of the British Mandate over Palestine. Alas, this is the same tactic used by the Greeks in Turkey today. ${ }^{68}$

The conclusions as to the policy Turkey should adopt towards Israel are selfevident: the close bilateral relationship with Israel would transform Turkey into a Middle Eastern country detached from Europe or into a confrontation state in conflict with Iraq, Syria and Iran - effectively with the entire Arab world. Moreover, the rapprochement with Israel is at the expense of potential Turkish links with the Balkan states, Greece, and the Turkic republics of Central Asia. All this would be a boon to Israel, but a burden on Turkey: the latter had paved the road but Israel would reap the fruits. The conclusion: "Let us not make Israel our enemy but let us not get too close." ${ }^{69}$ Defining the Israeli-Turkish rapprochement as the most significant development in Turkey's foreign policy in the past fifty years, the writer, Aydin Menderes of the Refah, drew the disconcerting conclusion that Turkey has no proper assessment of the drastic consequences and damage arising from this change. "Unrestricted Turko-Israeli friendship is unrealistic," he affirmed. ${ }^{70}$

Many in Turkey found these anti-Israeli, even anti-Semitic tones disturbing. Several months ahead of the formation of the Erbakan government, President Demirel offered the following comments in an address to Turkey's National Security Council:

Are the Turks, who did not engage in anti-Semitism 500 years ago, now to become anti-Semites? . . Was the Islam of 500 years ago more progressive than the Islam of our time? Is that which was not done then [i.e. anti-Semitism, persecution] to be done now? If Refah achieves office, it will have to display tolerance and equality, which were granted to Jews, Armenians and Greeks by the Sultan 500 years ago. ${ }^{71}$

Indeed, when the Refah took office, a change did become evident. Amazingly, when Erbakan's term of office came to an end, his government found itself praised for its activist policy towards Israel! Refah representatives did not boycott Israel. On the contrary, at the governmental, parliamentary and municipal levels, Refah ministers, members of parliament, and mayors acted to reassure the Jewish community, as well as holding overt contacts with diplomats from the Israeli embassy. It seemed that above all the benefit of Turkey's interests called for businesslike relations with Israel, devoid of the ugly rhetoric mentioned above. ${ }^{72}$ The Islamic press even underwent a process of "soul-searching." 
Its conclusion held the Refah Partisi (RP) to blame for the situation wherein Israel was Turkey's sole friend. Were it not for Refah's enmity towards the West, Europe, and the EU, Turkey would not have been left with no ally but Israel. ${ }^{73}$

On leaving office in mid-1997, the Erbakan government (including, it will be recalled, the Refah along with Tansu Ciller's “True Path Party," better known as the Refah-Yol coalition), gained startling praise for the policy of rapprochement with Israel adopted during its term in power. Ambassador Elpeleg likewise offered his praises. In response to the question: "What is preferable: a meek Erbakan within the government, or an Islamic movement - unbridled, antiIsraeli and anti-Western - excluded from power?" he replied:

Things look different when seen from the Turkish end. There are numerous advantages to Erbakan being in power - first and foremost from the viewpoint of the grave socio-economic difficulties afflicting Turkey. Erbakan's party is presently the only party to take heed of the tribulations of the millions deserting the villages in the East and streaming into the large cities, the only party attempting to combat retardation. ${ }^{74}$

We shall conclude this section of the chapter by quoting the words of Nazif Akumus in Yeni Gunaydin, where he summed up the Refah-YOL coalition and its Israeli policy, suggesting, in "a mixture of humour and reality," that Israel would miss Erbakan:

During the Refah-Yol government, it was assumed that relations with Israel would be impaired (albeit not suspended) and that the warm atmosphere would cool down and that there would be a reversal to the previous climate. However, Necmettin Erbakan surprised everybody in this matter, as in others. He contributed to fostering the relations with Israel, whom he had been accusing for years of being the architect of "Zionism." So much so that the news arriving from Israel last month, following the demise of the Refah-Yol government ... was accompanied by remarks such as, "we were more comfortable, and our relations were more mature, during the Refah-Yol government." What's more, the headlines of an Israeli paper - "we miss the $R P$ government" - reflected a mixture of humour and reality.

Although the agreements with Israel evoked reactions in the Arab world and angered some radical groups in Turkey, we consider it the most appropriate policy of recent years in Turkish foreign policy. Particularly on the terrorist issue, we believe that both countries, marching hand in hand, will take the Middle East a long way forward. We have observed some of the results and we have more hopes for the future. ${ }^{75}$

\section{Turkey-Israel: the military aspect}

Israeli-Turkish military cooperation touches upon a number of principal domains: air, sea, land (infantry, armour), aircraft industries, armament industries, missile manufacture, intelligence, and so on. The financial aspect of this interaction is unknown - modernization of Turkish military planes and armour 
in Israel is among the few items whose cost has been made public - but is easily assessed as running into hundreds of millions of dollars if not more. The flow is not exclusively one way - that is to say, Israeli military sales to Turkey. On the contrary, Israel pays for use of sophisticated Turkish military installations and installs Turkish-made components in its weaponry. Cooperation is close, institutionalized and structured: steering committees, regular meetings, strategic dialogues at fixed intervals, with the hierarchy of deliberations reaching the most senior echelons, i.e., defense secretaries or even higher. Sales of Israeli weapon systems to Turkey frequently include cooperation with local manufacturers who produce some of the components, or share in assembling the final product. Thus, systems for locating and rescuing pilots are manufactured in Israel (by the Tadiran corporation), but assembled in Turkey by the local munitions concern, Aselsan. ${ }^{76}$

The Reliant Mermaid, the annual American-Turkish-Israeli tripartite naval rescue exercise held in the Eastern Mediterranean since early 1998, hinged upon the purely humanitarian effort of maritime rescues. The parties thereto were revealed to the public, leaving room for conjecture that Israeli-Turkish interaction, the surprising Jordanian attendance (composing together "The region's three sane countries"), ${ }^{77}$ and the American backing it receives, are now sufficiently robust and profound to permit the parties to exhibit their shared nonmilitary endeavors. Indeed, the navies of Turkey and Israel hold maritime exercises, and operation Reliant Mermaid was preceded by naval maneuvres in the summer of 1996. In addition, the Israeli navy trains at Turkish diving facilities, where it benefits from lower prices than the equivalent cost of such special training in Germany or Britain. ${ }^{78}$

Intermittently - arousing by this the concern and wrath of its Arab sisters Jordan deviates from the Middle Eastern Arab vehement objection to the Israeli-Turkish cooperation. Accordingly, Jordanian officials and navy officers attended the Reliant Mermaid and other Turkish-Israeli military forums. This is an understandable, prudent move, by an inherently weak country - more than 3 percent annual population growth, 30 percent unemployment, 30 percent living below the poverty line, 3,500 dollar GNP per capita, a 7 billion dollar foreign debt - which is periodically threatened by its mightier Arab neighbours, as well as by Muslim and Palestinian radicalism. Started in 1996, secret TurkishJordanian military cooperation - secret for fearing other Arab countries' vociferous condemnation - was extended to the above mentioned trilateral contacts. Interestingly, it was Jordan's King Hussein who initiated this extension. In April 2000 a Turkish jet fighter crashed, its pilot killed while training in Jordan, thus revealing the extent of Turkish-Jordanian cooperation. More intriguing is the Jordanian airforce becoming the third "leg" to the aerial interaction between Turkey and Israel. A low-profile 1984 Turkish-Jordanian military cooperation agreement, turned in the late 1990s into intensive interaction, "the most significant cooperation [that Turkey has] other than NATO." It included regularly conducted reciprocal high-level military visits, a telephone hotline service 
between military commanders, exchanges of troops for training purposes, and aircraft use of one another's air space for training runs. The Turkish airforce provided training programs to Jordanian pilots and ground personnel: Jordanian F-16 pilots underwent flight simulation training in Turkey, and Turkish-built $\mathrm{CN}-235$ light transport aircraft were leased to Jordan. Exchanging infantry troops increased steadily since 1997: from infantry squads, to fully equipped battalions, to entire divisions in 1999. Land forces from both countries are trying to familiarize themselves with the different topographic conditions of Turkey and Jordan, and the troops from both countries were transported with Turkish C130 (Hercules) cargo aircraft. Most interestingly, both armies have been training each other in cartography and in language. Military teachers from both countries are assigned to one another's military academics, where Jordanians teach Arabic to Turkish cadets and Turks teach Turkish to Jordanians. ${ }^{79}$

Israeli-Turkish military cooperation is reported in detail in world media, and we shall list here only its principal elements. Most of the bilateral military exercises are kept under heavy secrecy. Computerized battlefield simulations for the land forces are conducted regularly in Turkey and Israel. In one of the war games both countries troops - up to the battalion level - served as peacekeepers in a virtual country examining, inter alia, their ability to act in harmony. Israeli officers found these simulations to be of particular value because of the experience the Turkish side has gained in similar NATO exercises. ${ }^{80}$

The modernization in the Israel Aircraft Industry (IAI) of Turkish planes fifty-four F-4s (Phantoms) and forty-eight F-5s - at a cost, including interest, of 900 million dollars, is probably the most publicized military deal done between the two countries. ${ }^{81}$ Under the December 1996 agreement, upgrading of the F$4 \mathrm{~s}$ is to be completed by 2006-8; the first plane will be dispatched back to Turkey thirty-three months after its arrival in Israel. (Turkish critics claimed that the F4s would end their metal life in 2010 and shortly afterwards the planes would have to be grounded, hence the entire package lacks any military or economic rationale.) The Turkish planes are to undergo structural improvements, and be fitted with radar systems, computerized aeronautical systems, navigation systems, electronic warfare systems and armament to improve the planes' performance in bombing missions. The IAI also will do the upgrading of the Turkish airforce C-130 cargo aircraft. The Israeli C-130 modernization package solves the financial problem of airforces that have hundreds of C-130 but are finding it difficult to replace them with the modern version (C-130J). Among other benefits, these upgrading projects are of importance to Israel in creating thousands of jobs in its aircraft industry. ${ }^{82}$

The contract for modernization of the F-4s was prefaced by a February 1996 agreement for mutual military visits, training and exercises, dispatch of observers to oversee military exercises, staff exchanges, and acquisition of military know-how. By virtue of this agreement - concluded for a five-year term and subsequently to be extended annually - the two airforces and navies are to hold mutual visits and joint exercises. Concomitantly, the agreement stresses that 
when the soldiers of either signatory are on the territory of the other, they shall not be involved in conflicts between the host state and any third party. ${ }^{83}$

The training exercises of the two airforces are held eight times annually, a week each time, four deployments in each country. The joint exercises in Turkey (at first joint exercises were excluded, hence the Israelis trained without the participation of Turkish planes, without armament, and without electronic surveillance equipment), are held at the Konya firing range. Overland exercises are a novelty for the Israeli pilots, improving their skills in dealing with land targets; due to Israel's diminutive size, the Israeli airforce generally trains over the Mediterranean. Turkish pilots train at Israel's computerized firing range, and at the Nevatim airfield. In June 2001 a triple cooperation took place when American Air Force F-16s deployed in Germany joined the training over Konya. (The Anatolian Eagle, the tri-party aerial cooperation for 2002, was supposed to include thirty warplanes from each of the three participants). ${ }^{84}$

There were also non-combat features in the two airforces' activity; their interaction is so intensive that they could also afford the ceremonial side. For instance, Israeli F-15s took part in an aerial display in Turkey (June 2001), to celebrate the ninetieth anniversary of the Turkish airforce. Likewise, Turkish airforce senior officers and combat pilots came to Israel and participated in a highly televised event to commemorate the flight of two Ottoman pilots ("the Neil Armstrong and Charles Lindberg of Turkey"). The two crashed (1913) with their small French-made aircraft near the Sea of Galilee, on their way from Istanbul to Alexandria. ${ }^{85}$

Another domain wherein Israel and Turkey - and since 1999 the Royal Jordanian airforce - collaborate is their airforces' intentions to establish a radar network to pinpoint and identify migration routes of predatory birds in the autumn and spring, to minimize the chances of aircraft-birds collision. Altogether, some ninety Turkish F-16 pilots have already received training in relation to bird-plane collisions and related Israeli safety regulations. (In 1995 an Israeli F-15 crashed, its two pilots killed, following a collision with a bird. During the last twenty-five years 170 European and Israeli military aircraft were badly damaged, and more than thirty pilots killed, in aircraft-bird collisions.) Seven radar stations are to cover Turkish and Israeli airspace, providing updated information on bird migration along the Europe-Africa route. Turkey will be able to give Israel and Jordan a two-day warning of the autumn migration, while Israel and Jordan will provide Turkey with a similar alert in advance of the spring migration. ${ }^{86}$ It seems that the same thinking that the Reliant Mermaid disseminated, is applicable here as well: the real interaction between the air forces is sufficiently robust which enables them to exhibit their shared nonmilitary endeavors

When the airforces' training proved successful, other areas were included. Sales were reported of the Israeli Python 4 air-to-air missiles to Turkey and of the Israeli made Ehud reconstruction system for the Turkish airforce dog-fight training. (Ehud enables the reconstruction of all flight stages, plus a warning system 
against mid-air collisions between aircraft.) Refuelling tankers were also supplied to the Turkish airforce; the cost would be covered by credit given by Israeli banks to the Turkish airforce. In August 1996, an agreement was concluded between the two countries' arms industries. Various publications point to Israeli-Turkish collaboration in manufacture and sale of the Popeye surface-to-air missiles; Turkish manufacture of the Israeli infantry rifle, Galil; formulation of defensive doctrines against ballistic missiles; eventual Turkish participation in production of Israel's Hetz (Arrow) anti-missile-missile; and joint manufacture of the jet-propelled, $400 \mathrm{~km}$. range Delilaha cruise missile. It was also reported that the Turks voiced great interest in intelligence and other data transmitted by the OFEK satellite that Israel has recently launched into space. ${ }^{87}$

The offer of the Israeli Merkava (Chariot) Mark 3 tank for sale to Turkey, and modernization of Turkey's M60A3 (Patton) tanks, mark growing interaction between the two countries in relation to their ground forces. Turkey's armoured units comprise 3,000 Patton tanks, 900 of which are suitable for upgrading. Israeli tank-promotion proposals include fitting the Patton with a $120 \mathrm{~mm}$ Merkava gun, endowing the aging tank with new artillery capabilities in range and the penetrative power of its shells. The Patton's American engine will be replaced by the $1,000 \mathrm{hp}$ German MTU one. In all, the upgrading project will include improvement in the tank's artillery capability; an improved capacity for survival by more effective armouring; improvement in the precision of the "tankionics" by installation of an advanced fire-control system and command systems; day and night vision systems for the tank commander and gunner; and improving the tank's performance by installation of a stronger engine, etc.

The saving in time and money makes it probable that the Turkish army will adopt the Israeli offer: modernization of a Patton takes two months, at a cost ranging between 1 million and 2.25 million dollars; a new tank, it should be recalled, costs 5-6 million dollars. (Indeed, the Turkish army has examined the procurement of new tanks - the Abrahams, the LeKlerk, the Challenger, the Leopard, and the T-90 Main Battle Tank, offered to it by the United States, France, the UK, Germany and Russia, respectively.) Within a short while major parts of the work could be done in Turkey in a production line for upgraded Pattons, offered by TA'AS, the Israeli military industry, to MKEK, its Turkish parallel.

But the tank deal is of wider importance: closer bilateral relations require Israel to discard the veil of secrecy surrounding its weapons development programmes. With growing collaboration between the two defense establishments, Israel increasingly shares its arms production secrets with Turkey. This becomes obvious with the offer to sell Turkey the Merkava tank: as part of the agreement on cooperation in military technology, Israel is willing to set up production lines for the Merkava in Turkey. Israel's arms supply has thus been attractive to Turkey because it is followed by the transfer of military technology and knowhow. (There is one exception: the transfer of Israeli technology or weapon systems that were developed with American participation is subject to US approval, which is not always granted.) 
This clearly coincides with Ankara's declared policy of becoming more selfsufficient in meeting its own military requirements. Mutual trust thus brings about mutual interests that produce mutual dependency, and all combine to create collaboration in the most sensitive and secretive domains. Next to the close cooperation that the IDF, IAI and TA'AS have with the US armed forces and military establishment, the level of intimacy with the Turkish military is of the highest degree. ${ }^{88}$

A number of elements here come together: Israel's position as fifth in rank among the world's arms producers; Turkish plans for arms procurement, modernization and refitting for its army which is the largest in Europe and second only to the US army in NATO. Approximately one-third of Turkey's annual military budget is devoted to modernization and weapons upgrading. These plans run in the stunning range of 150 billion dollar over the next twenty-five years ( 60 billion dollars for the ground forces, 25 billion for the navy and 65 billion for the airforce). And, as noted, the fact that local production of weapon systems covers a mere 21 percent of Turkey's needs produce calls for more self-sufficiency. In addition, Israel is ready - in particular its Foreign and Defense ministries - to increase its imports from Turkey and to lower tariffs and customs on imported Turkish goods (cement, cast iron, textiles, food, agriculture products, etc.), even at the expense and protest of local producers who face bankruptcy. The story was apparently a simple one: the economic crisis in the Far East strongly hit Turkish steel exports to that region. The next step was the damping of the Israeli market with cheap Turkish steel. Turkish iron, offered in Israel for 230 dollar a ton, is cheaper by 40 dollars in comparison to locally produced cast iron. NESHER, the Israeli cement industry, was more successful: it managed to keep its monopoly by enforcing a high tax over the import of Turkish cement, thus infuriating Turkish cement exporters and Israeli customers, who look for cheaper cement. The need to buttress the strategic cooperation justifies Israeli deficits in its civil trade with Turkey. ${ }^{89}$

Turkey is also considering the manufacture of a helicopter suited to its needs, and is looking for a partner; it intends to produce in Turkey some 95 percent of the aircraft's components. Thus, Turkey's defense needs, the Israeli arms industry, and Israel's willingness to share with Turkey its manufacturing techniques, and its readiness for joint production of weapons, thereby stepping up Turkey's local output, all combine to generate the expansive and qualitative military cooperation portrayed here..$^{90}$

Intelligence cooperation constitutes a principal span in Israeli-Turkish rapprochement. This is a domain in which speculation is rife, but Turkey's location between the three states of special interest to Israel (Syria, Iraq, Iran), and Israel's joint border with Syria (a matter of interest to Turkey), leave little scope for assuming anything but the existence of close Israeli-Turkish intelligence ties. The two countries act extensively in scrutinizing initiatives for the development of non-conventional weaponry in the Middle East, keeping watch on occurrences of radicalism, and ideological or religious terrorism, threats to energy 
sources in the Middle East and Central Asia, developments in the Muslim republics of Central Asia and Iranian influence in that region, etc. Intelligence cooperation between Israel and Turkey comprises exchanges of information, routine intelligence briefings, analyses of data, including that collected by Israeli satellites, and tripartite deliberations involving agencies from the United States, Israel and Turkey.

\section{Civil cooperation}

With the purpose of tempering criticism, domestic and external, over its military collaboration with Israel, Turkey stresses that the military element is no more than one portion of the interaction between the two countries. The contract for modernizing the Phantoms is nothing extraordinary, claimed the Turkish paper Zaman, citing the then Foreign Minister, Tansu Ciller, to specify details of existing agreements between the two countries. Israeli-Turkish annual trade already reaches a volume of one billion dollars - weapons and tourism excluded - the largest volume of bilateral trade between any two countries in the Middle East. Fifteen percent of Turkey's Middle Eastern trade - oil-producing countries inclusive - is with Israel. The Israeli-Turkish Free Trade Agreement (FTA) signed in 1996 and ratified in April 1997, and the custom-free arrangements and agreements for the avoidance of double taxation that each country has or plans to conclude (for instance, Israel with the Unites States, Turkey with the EU, etc.), opened new venues. Current trade already enjoys these agreements: Turkey sells duty-free products to Israel; Israel adds its own finishing and sells them free of duty to the United States. Indeed, since the ratification of the FTA and the inclusion of textile and agricultural products in the agreement, the bilateral trade volume increased by 100 percent. All project 2 billion dollars or more in mutual trade from the early years of the twenty-first century. Optimists claim that multibillion figure to be on top of military trade and the movement of tourists between the two countries. Alongside close military ties - roughly one-third of bilateral relations - there is extensive and much larger civil interaction between Turkey and Israel, with great potential for further expansion and longevity. The bodies that plan the future relations stressed they were aiming at a realistic 4 billion dollar annual bilateral cooperation. ${ }^{91}$

Zaman specified thirteen spheres of Israeli-Turkish agreement and cooperation, correct for October 1996, eleven of them of non-military in nature. ${ }^{92}$ This interaction is to be found in the fields of culture, education and science; cooperation relating to environment and nature protection; mail and telecommunications; the campaign against smuggling of drugs and narcotic substances; health and agriculture; regulation of trade free of customs and duties; encouragement and protection of financial investments; prevention of dual taxation; agreements on technical and economic cooperation, etc. For comparison with IsraeliTurkish trade links, it is worth studying Turkey's commercial ties with Greece. 
Overshadowed by the dispute between the two countries, mutual Turkish-Greek trade attained a volume of a mere 430 million dollars (year 1995) for a joint population that comprises 75 million. Businessmen from the two countries agreed that, were mutual trade to reach 2 billion dollars, politicos in Ankara and Athens would be more circumspect about disrupting bilateral relations. ${ }^{93}$ In view of the data relating to current trade, and the outlook for the years to come, Israel and Turkey seem unlikely to allow the disruption of relations between them.

Israeli-Turkish trade has taken a significant quantum leap. In 1991, mutual trade totaled 100 million dollars; by 1995, it had passed the 440 million dollar mark; and by 2000 it approached the 1 billion dollar target. As a further illustration, in 1987, Turkish exports to Israel totaled 19.8 million dollars, while Israeli exports to Turkey came to 34.3 million dollars. In other words, mutual trade totaling 54.1 million dollars is less than 5.5 percent of the current figures.

Up to 1993, Israel held the upper hand - its exports to Turkey exceeded Turkish exports to Israel. As of 1994, Turkey has steadily pulled ahead, with an annual surplus of 50 million dollars in its favour. Turkish exports to Israel include, among other things, textiles, industrial products, food products, cement, cast iron, building material, electronics, glass, stone items, car tyres, raw materials, grains, cement, and major construction projects like the NATBAG 2000, the extension of the Ben-Gurion airport in Tel Aviv. The main constituents of Israel's exports to Turkey are chemicals, plastics, computers, air conditioners, medical equipment, telecommunications, drilling and seismic mapping, medical insurance policies for the use by Turkish citizens in Israeli hospitals, irrigation equipment, etc. In February 2000, six agriculture irrigation projects totaling 600 million dollar, part of Turkey's GAP (Southeastern Anatolia Project), were allocated to Israeli companies. By virtue of its geographical proximity, Turkey's hightech exports to Israel, including products of assembly electronics, compete successfully with electronic firms from the Far East, as well as with their Israeli counterparts. The average monthly wage of a Turkish production worker is 300-400 dollars; an engineer makes 1,000 dollars. Parallel Israeli figures are 300 percent higher. In 1992, for instance, monthly minimum wage in Turkey was 210.80 dollars, the equivalent figure in Israel was 507 dollars. Since the late 1990 s the gap has widened because of the economic crisis that Turkey suffers from. However, one of the results of the crisis has been that more Israeli companies have moved their factories to Turkey; on average their spending on labour wages has reduced by 58 percent. ${ }^{94}$

Israeli-Turkish commerce is also affected by Turkey's trade links with the EU. Under the customs union agreed in January 1996, duties on goods traded between Turkey and the EU are being phased out progressively - 70 percent of the reductions had been completed by August 1993, the remainder are in the process of accelerated elimination. However, elimination of Turkish duties on imports from the EU had a detrimental effect upon Israeli exports to Turkey and their competitiveness with the European products. This was partly rectified when the Turkish-Israeli free trade zone came into effect. ${ }^{95}$ 
Israeli tourism to Turkey is likewise a flourishing Turkish export sector, so is the joint venture of marketing Turkey and Israel together to tourists from Japan and the United States. Some 350,000 Israelis have visited Turkey annually since 1994 - altogether, 15 percent of the Israelis who took trips abroad chose Turkey - spending an average of 1,000 dollars per head, while their casino wagers (i.e. losses) come to 1.5 billion dollars annually. For comparison, the annual sum total of all betting in Israel is 1.5 billion dollars. ${ }^{96}$ With an annual turnover of 1.85 billion dollars, the tourist industry further tilts the bilateral trade balance in Turkey's favor. The number of Israelis visiting Turkey has recently dropped: in 1997 it was down to 300,000 as it also was in 2001 . The reduction in numbers of casinos is one reason, but the Turkish ambassador to Israel explained that "Israeli tourists want to travel overseas." In other words, Turkey has become "too Israeli" for their taste, and they see no obvious difference between a vacation there or at home. Still, by the year 2002, the number had not declined any further.

Israeli tourism in Turkey, and Israeli-Turkish commerce, reflect the robust character of bilateral relations. Nothing can compare with civilian trade as an illustration of the extent of interstate relations. Only a calm climate of confidence in long-term relations could facilitate trade on the scale specified. Tourists and investment in tourism - possibly the element most indicative of a friendly, relaxed atmosphere, and confidence in its preservation - are the most prominent characteristics of extensive non-military relations between Israel and Turkey. In 1986, 7,000 Israelis visited Turkey; in 1992 160,000; and, as already noted, from 1994 onwards some 300,000-350,000 annually, out of some 2 million Israelis touring the world each year.

Cultural Turkish-Israeli exchanges thrive. People to People projects and more than thirty agreements enable contacts between Turkish universities, research institutes, and medical schools. The University of Ankara, the Middle East Technical University, Bilkent, Bogazici, Galatasaray, Bilge, Konya, Antalya, and Kirikkale have been visited by scientists and faculty from all seven Israeli universities and scientific research centres. Hundreds of trainees from both countries have participated in scientific seminars and instruction courses. Violinists, pianists, and other musicians, opera singers, orchestras, ballet and dance groups, perform at each other's festivals. ("Cafe Istanbul" was the name given to the performance of Turkish musicians in Israel in winter 2002.) Turkish and Israeli film weeks, architecture, painting, carpet and photograph exhibitions won much success and acclaim. The Ottoman carpets exhibition in Jerusalem, and the Israeli "Bread" photograph exhibition, drew large crowds. The latter, shown in Istanbul in June 1998, centred on the many symbolic meanings of bread in different cultures. The Turkish Cancer Association displayed photographs of the Israeli model, Ariella Shavid, who had her breasts removed owing to cancer. Shavid went on with her life, without altering her post-surgery appearance, sending a message of courage and pride to other breast cancer patients. Turkish university students who spent their summer in Israeli kibbutz; high-school students from Israel who visit schools in Turkey, lecture and show 
videos, and are hosted by Turkish families with children of similar age, have added a great deal to the People to People projects. ${ }^{97}$ The result of all this is that broad circles of Israelis and Turks have a direct interest in continued contacts, in enhancing their business, and preventing or minimizing any upheavals between Ankara and Jerusalem. Recalling the aforementioned example from Turkish-Greek relations, politicians and soldiers in both places may be expected to do their utmost to prevent the collapse of the bilateral relationship.

However, problems do arise. Political and religious objections, as well as economic and commercial complaints, intermittently threaten to mar the above described rapprochement. Turkish employees in Israel experience poor working conditions, their passports are kept by their employers, and companies usually do not pay their full wages to discourage them from leaving for better jobs. Those who nevertheless prefer not to stay on, do not see their passports again: the companies, so the rumour says, sell the passports in Istanbul, now stamped with the highly sought-after Israeli work permit visa, to new job seekers. Alternatively, the Turkish embassy in Tel Aviv demands 700 dollars for a new passport..$^{98}$ On the other hand, complained the Turkish daily, Radikal, "Our workers get into trouble for harassing women." And when the Israeli police imprison foreign workers and detain them (in "concentration camps") till their deportation procedures are finalized, the real reason is revealed: "It is the U.S. who is enforcing this. The U.S. wants Israel to employ Arabs and get on with the peace process so they have asked Israel to send back all foreign workers." ${ }^{\prime 9}$

Neither was military cooperation devoid of any friction. The Turkish media differed as to the value of intelligence Turkey gets from Israel. Sabah praised the satellite pictures of Syria, which were full of top-secret military information, including indications as to the inferior weapons that country deployed along its border with Turkey. The Milliyet, however, complained that contrary to the two countries' intelligence-exchange agreement, Israel avoided supplying Turkey with updated intelligence on Syria. What it did eventually supply Turkey with, was information available to the public, not secret photographs of Syrian troops taken by the Israeli satellite, OFEK- $4{ }^{100}$ Similar complaints were raised in relation to the upgrading of the Turkish F-5 aircraft, which the IAI won the tender for through a proposal "based on shrewdness." The consortium that won the bid appeared to be from Singapore; it turned out at the last moment that the bidder is actually the IAI. Moreover, after the aircraft-modernization agreement was signed, Turkey insisted that the multifunction display that would be fitted in the F-5, would be of the Israeli-made Elbit type, and identical to the avionics that exists in the Israeli F-16 jet fighters. This was to cut down the duration of training because Turkish pilots, before moving to the advanced F-16, had first to prove themselves on the F-5. The IAI refused and insisted on inferior systems being installed in the F-5, demanding instead higher payment for the Elbit product. In the same bid the Turkish aircraft industry had increased the number of locally made systems, for instance the VHF/UHF radio systems fitted in the F-5. Still, complained the Cumhuriyet, although the IAI was asked not to calculate 
these radio appliances, the final fee to be paid to the Israelis included payment for such systems. On the other hand, Israel complained about the quality of Turkish military export to Israel: a tender won by an Israeli producer for the supply of 5,000 special commando uniforms with bullet-proof vests was passed on to a Turkish company. Alas, it was found to be below the standard - the vests were not resistant to bullet and shrapnel - and the tender was cancelled. ${ }^{101}$

During a visit to Israel of Prime Minister Mesut Yilmaz (September 1998), Benjamin Netanyahu greeted his Turkish guest. The following quotation from Zaman might be a good example of the various aspects that are interwoven in the bilateral relations. It binds together Turkey's sensitivity in relation to its Ottoman pride with its hectic secular-religious present; the uncertainties, terror and violence that the city of Jerusalem is coping with; and Israeli sensitivity to the Holocaust:

Netanyahu must have advisors who know Turkey very well, [so] he spared his best words for Ataturk. Among all the niceties about Ataturk, his words, which should have offended us, went unnoticed. These words were about the situation in Jerusalem at the beginning of the century: "Apart from the wall built by Suleiman the Magnificant, Jerusalem was in a pitiful state, with arid land," said Netanyahu. Maybe that was the case but in those days Jerusalem was in the hands of the Turks and it had not become the scene of terror yet. At least its status was not under discussion. Everyone who visits Israel is taken to Yad Vashem. I had different feelings while going around in the museum this time. I spent a long time in front of one picture. The picture was of a group of judges and underneath it said, "This is the photo of judges supporting the Nazi regime." I felt like crying while reading this. We must start collecting material for a future museum to commemorate the oppressed people of 28 February. [On 28 February 1997 the Turkish military presented Prime Minister Necmettin Erbakan with a list of demands. This ultimatum eventually brought Erbakan's resignation. See Chapter 4]. ${ }^{102}$

If still needed, this quotation is yet further evidence of the close contact between internal and external affairs that the bilateral Turkish-Israeli rapprochement raises.

\section{Opposing forces: Arab and Muslim reactions}

It would be an understatement to argue that Israeli-Turkish relationship is not popular in the Arab world. Apparently, the parallels are obvious: the Arabs have lost Palestine and Alexandretta, and blame for those setbacks falls upon Israel and Turkey, respectively. The Arab world and Iran pursue continuous campaigns against both countries, albeit "on the back burner" and by means of surrogates: Syria assails Turkey by means of the PKK underground, and Israel by means of the Lebanese Hizbullah. Israel's security zone in southern Lebanon (evacuated in May 2000) and its Turkish parallel in northern Iraq, are - in the Arab view - outright additional conquests. (Privately, Turkish officials disliked 
the Israeli withdrawal from the Lebanon: it undermines our presence in northern Iraq, they said.) A harshly violent historical legacy - also colonial in Turkey's case - leaves its mark on the Arab world's relations with Turkey and Israel. Most Arabs regard both countries as an affliction, a Middle Eastern subsidiary of the ugly and secular sides of Western civilization. The two together form a Western thrust - also of military features because of Turkey's membership in NATO into the core of the Muslim and Arab world. The Turkish case also poses a cultural threat: Ankara could be presented as a model of a democratic and secular state for Arab and Muslim countries to emulate, and to serve as a bridge between East and West. ${ }^{103}$ The Arab response, therefore, reflects bitterness, emotions, phobia, anxiety, etc. See, for instance, Arab accusations, repeated in Turkish newspapers, that when crossing Turkish territory, Israeli agents placed crocodile eggs in Iraqi lakes.

The Arab reaction included, inter alia, displays of alienation toward, and denial of legitimacy of, the Turkish-Israeli cooperation, and calls for the establishment of counter-steps and coalitions. However, verbal reactions were the most the Arab world afforded vis-à-vis this bilateral cooperation. (Interestingly, the Hellenic world or the Kurds acted in a similar way: there was only one single violent Kurdish reaction - the raid in February 1999 on the Israeli consulate in Berlin following the capture of Abdullah Ocalan.) Syria and Iraq, supposedly the countries most negatively affected - Syria by the pincer-like grip and Iraq by the Turkish security zone in its territory - took care not to antagonize mighty Turkey. Baghdad was doubly cautious because Turkey and Jordan (another party, albeit a junior one, to the Turkish-Israeli cooperation), are Iraq's only export exits. However, Turkey was excluded from the role of hosting or facilitating in any way the 1990s peace talks between the Arabs and Israelis. The Arab partners concerned were totally opposed to granting Turkey such a role because they did not want to strengthen its standing in the region, especially because of Ankara's links to Jerusalem. ${ }^{104}$

The term "perfidy" is commonly bandied about between Turkey and the Arab world. Such was Arab aid to Britain in its war against the Ottoman Empire; Egypt's assistance to the Greek Cypriots in their war against the Turkish Cypriots; Turkey's recognition of the state of Israel; and Turkey's steady, principled support for the continued presence of the Western powers in the Middle East and North Africa, in direct opposition to Arab nationalism. The following figures illustrate the "chill" between Ankara and its mid-eastern neighbours: 1982 marked a zenith in trade relations between Turkey and the Arab world; 44 percent of Turkey's exports, and 29 percent of its imports, were with trading partners from the Arab Middle East. A steady decline has reduced these figures to a low: by 1996, they had fallen to 11 and 8 percent, respectively. ${ }^{105}$

Matters were not always in such a wretched state. The Muslim common denominator was brought to the fore, in particular during the prime ministership of Necmettin Erbakan, as a means to strengthen the Arab-Turkish bond at the of expense the Turkish-Israeli one. As mentioned previously, no deterioration 
was recorded in the bilateral relations during the short-term government of Erbakan. Also, raising the Muslim common nexus was greeted with little enthusiasm by the secular and military elite of Turkey.

It is interesting to note the remedy proposed by Khaled bin Sutlan bin Abed al-Aziz, a scion of the Saudi royal family, son of the Saudi Defense Minister, and proprietor and publisher of the Al-Hiyat newspaper. Thriving economic interactions - the basis for the intensive Turkish-Israeli cooperation - is also the recipe for bettering Arab-Turkish relations. After a doleful description of the grave consequences of the Israeli-Turkish alliance, the writer poses the following question and answer: "How then can we prevent Turkey's dissociation from its links of friendship and support with the Arabs? Solely by granting supreme importance to mutual economic interests. It is vital to find a form of economic integration between the Arabs and Turks, even if it is a gradual process." ${ }^{106}$

Before their very eyes, the Arabs witnessed the emergence - free of the inhibitions and constraints of the cold war - of a renewed "Baghdad Pact" which, since the 1950s, bears the infamous connotation of an anti-Arab means, with Turkey acting in contrast to Arab national aspirations. The unleashed regional powers, be they Turkey or Israel, are much more dangerous because this time they are not curbed by the Soviet Union. The two were portrayed as a living proof of the Arab collective weakness, if not as an existential nightmare. The 1990s version of the new Baghdad Pact is composed of Turkey and Israel, but as in the past is serving Western colonial aspirations and is viewed as offering threats. It brandishes the water weapon, very clearly spelled out by Ofra Bengio and Gencer Ozcan: "Put bluntly, the fear was that the Arab 'oil weapon' would be 'overwhelmed' by the Turkish 'water weapon."' ${ }^{107}$ It possesses military technology, Israeli nuclear monopoly, industry, territory, a large population, and controls regions and areas thick with crossroads of unrivalled importance. Revival of Ottoman hegemonic dreams and renewed subjugation of the Arab peoples were not excluded. Reactions and proclamations were swift: "The Turko-Israeli treaty - the most perilous milestone in the Middle East since the First World War ... comprises the ambition to draw a political and economic map based on water, by means of the Israeli-Turkish gun and with United States backing." ${ }^{108}$

An Egyptian newspaper contrived to list the detrimental effects an Israeli-Arab peace would exert upon Turkey - suggesting that Turkey favoured continuation of the Middle East conflict. The Kurds, said the newspaper, would envy and copy the Palestinians. Syria, relieved of its front with Israel, would concentrate on its dispute with Turkey. Opposition by Iran and various Muslim movements to the peace process would sharpen differences and provoke clashes and conflicts within Turkey, already wrought with religious-secular standoffs. Turkey would come under growing pressure over Cyprus. The revival of Beirut and Haifa as business centres of considerable weight in the regional economy will enable those cities to replace Istanbul, the principal beneficiary from the devastation of Beirut. And so on. ${ }^{109}$ 
In addition to these, Arab sources watch, some would say with horror, how Turkey focuses again on the Middle East. They list Turkish reluctance to get entangled in the ethnic complexities of Central Asia, or confront the traditional influence of Russia, successor of the Soviet Union, as the power with a decisive say in that region. Here one can repeat Moscow's warning to Turkey against being carried away by Pan-Turkish fantasies, lest Russia would respond with Pan-Slavism, targeting Turkish and Turkic ethnic elements and Muslim concentrations. ${ }^{110}$ The Arabs are aware that Turkey's alienation from Europe causes it to divert its attention also to the Middle East, and accordingly to collaboration with Israel. "Turkey realised that while becoming westernised she has to establish relations in the Middle East as well. She thought Israel was the most suitable country to develop relations with." ${ }^{111}$ Yet, there was another factor that brought about the rapprochement between Turkey and Israel. Here is another disenchanted country as far as enjoying European sympathies:

The hatred against Jews is based upon religion, and against Turks on the many years of fear. While they [the Europeans] always remember when they cross themselves that the Jew crucified Jesus, most have made it a habit to scare their children with the threat: 'Be good, or else I will give you to the Turks'. Hatred has become second nature to the Europeans. ${ }^{112}$

That is to say, the need to balance European and Russian reservation, as well as hostile Greek and Armenian lobbies, even a critical American Congress, direct Turkey toward Israel, and back into the Middle East.

Turkey's prime objective seemed to be Syria and Iraq, not Tehran. An assault on the first, as part of the conflict between the two, would be less costly than an attack on Iran. (The same thinking is applied as regards Turkey's Jews. Arab sources preferred to blame the Jewish community there for forging the Israeli-Turkish alliance; it is evidently easier to accuse the Jewish community than the Turkish government. $)^{113}$ Hence, if Ankara is not restrained, additional Arab territory - such as Mosul in northern Iraq - could fall into Turkish hands, in addition to the plights that have already befallen Syrian Alexandretta and the Golan Heights. ${ }^{114}$ Thus, Arab fears of Turkey predated the TurkishIsraeli rapprochement. The latter, however, has added further fuel to the flames. It is an open account, warn Arab sources, still to be settled, not necessarily in Arab favour.

In view of the above, we should note the diagnosis - and remedy - proposed by the aforementioned scion of the Saudi royalty. Arabs have every right to be concerned, but they should ask themselves what brought about their break with Ankara, and how they should respond?

On the whole, Arab politics are wanting in the capacity for coping with rapid changes on the ground. Arab politicians wake up to discover that the situation has changed. The Arabs assumed that Eritrea would remain a loyal friend even after gaining its independence; they also assumed that Turkey would be on their side forever, even if it gained no benefit thereby. 
The Arab side did not comprehend the complexities of the internal situation in Turkey, or that country's regional and international considerations. This created a climate that could push Turkey even further into the camp of unfriendly countries. ${ }^{115}$

We have already specified the economic remedy proposed for healing TurkishArab relations. Interestingly, this remedy coincides with the thrust of this chapter, namely that flourishing economic ties are the nearest to a guarantee of good relations - as illustrated by Israeli-Turkish relations and, conversely, in their absence - in Turkish-Greek and Turkish-Arab relations. Second in rank are proposals for Turkish-Arab cultural collaboration: according to al-Aziz it is vital that Arabs and Turks start purging history books and textbooks of mutual insults. ${ }^{116}$ A good omen is Syria's readiness to alter the curriculum of Syrian schools so that the 500 years of Ottoman rule should not be regarded anymore as imperialism responsible for the Arabs' "worst tragedy," backwardness, and weakness. Conversely, Turkish texts still carry the negative image of the Arab as a bedouin, traitor, womanizer, uneducated and submissive. ${ }^{117} \mathrm{Al}$-Aziz also advocates military cooperation between Turkey, Pakistan and the Gulf states:

I do not propose that we in the Gulf purchase military services from other countries. On the contrary, it is a matter of recognition and consolidation of shared interests. As those countries could serve to defend us, we too, in the Arabian Peninsula, can enhance their strategic depth. We are important to them no less than they are important to us. ${ }^{118}$

Ostensibly, the Israeli-Turkish rapprochement has generated new alliances in the Arab world. It is still premature to assess their vitality, value or capacity for survival, and we will thus restrict the discussion to a mention of developments. One matter currently under discussion is an Egyptian-Iranian rapprochement. Meetings at senior levels - the first for decades - were held in Tehran and Cairo. The December 1997 Islamic Conference convened in Tehran offered a convenient forum for these discussions. However, further improvement of bilateral relations seems to be impeded by Cairo's apprehensions regarding Iran's role in Muslim terrorism in Egypt and North Africa.

Syria and Iran recently signed a series of agreements on boosting bilateral trade. At their conclusion, the sides voiced concern over Turkey's links with Israel, and discussed further expansion of their own relations in view of those links. Syrian-Iraqi relations have displayed an unexpected spurt recently, likewise explained by fear of the Israeli-Turkish alliance. Thousands of Syrian merchants were granted Iraqi entry visas to sell goods sanctioned for sale under the UN embargo on Iraq. Baghdad has also called off its anti-Syrian propaganda broadcasts from the "Voice of Arab Syria" (the station launched its broadcasts in the 1970s; Damascus is persisting in its counter-propaganda broadcast from the "Voice of Iraq," though the tone is now less hostile). Telephone links between Syria and Iraq have been renewed. Here, too, the ties are nascent, or, to be precise, the first after a two-decade rift; they are not marked by concrete political expressions but with Syrian concern lest it be tarnished by association with a "leper state" like Iraq. ${ }^{119}$ 
Joint exercises by anti-aircraft defense units from Russia and Syria were held at a Russian site in late September 1997. The units drilled with Russian S-200 surface-to-air missiles, designed for use against high-altitude planes. The exercises were defended as a response to the joint maritime exercises held by Turkey, Israel and the United States ("Reliant Mermaid"). ${ }^{120}$ Iran likewise explains the expansion of its army with the necessity of defending itself against what it terms "the Israeli-Turkish conspiracy."

In spite of the above, the harsh terms did not impede renewed normalization of relations between Ankara and Tehran. In November 1997, each of the two countries restored its ambassador to the other's capital, and renewed bilateral military consultations, as well as deliberations on subjects like terrorism, energy and trade. The contention put forward by Philip Robins, concerning Ankara's considerations in its policy vis-à-vis Iran, probably holds equally for Tehran's position towards Turkey. Robins suggests that Turkey does not have the luxury of geographical distance from Iran, and it therefore seeks ways of reaching an understanding with Tehran, albeit maintaining a critical approach towards Iran. The same could be argued in the reverse direction. ${ }^{121}$

Hitherto, the Arab and Islamic response to Israeli-Turkish relations features much talk but very little action. Counter-alliances have yet to emerge, and it is doubtful whether they will; the causes of the existing rifts within the Islamic and Arab Middle East still await removal, leaving opponents of the Israeli-Turkish rapprochement very frustrated and with few opportunities for action. Moreover, following the initial waves of wrath and anger, Turkish-Arab contacts seem to experience an upsurge. We have already mentioned the growing volume of Syrian-Turkish relations (see Chapter 4). Egypt, which in 1997 toyed with the idea of a Greek-Egyptian accord to counter-balance the Turkish-Israeli one has concluded (June 2001) a multibillion cubic meter gas deal with Turkey, a multibillion dollar buyer of Egyptian energy. The pipeline will run from the Egyptian town of Al-Arish to Ceyhan. Surprisingly, following Turkish insistence, a branch will connect it to the Israeli town of Ashkelon. Conversely, Ankara turned down the Egyptian plan to include Syria and Lebanon in the deal. Iran, a major gas supplier to Turkey did not like the Egyptian concurrence, but eventually blamed Turkey and Egypt for sacrificing their interests in favour of the Zionist and American ones. ${ }^{122}$

It seems that Iraqi dependency on water from Turkish sources leaves little scope for anti-Turkish démarches, and epitomizes the general Arab reaction depicted above. When the other side fires off remarks like "They have oil, we have water - let them drink their oil", anti-Turkish initiatives have to be cautious, and in fact are hollow.

\section{Epilogue}

The end of the decade was marked by a tragic event in Turkey - the earthquake of August 1999. A huge Israeli machine of help was set in motion and started yet 
another stage in Turkish-Israeli relations. The epitome of this diplomacy is the "Israel-Turkey Village" (called "Israil Koy" by its inhabitants) in Adapazari, which stood in the epicentre of the quake. It consists of 320 houses plus community buildings (shops, school, police station, playground, and clinic). The village serves as a model for the restoration of the town and other earthquakestricken people. A "We Won't Forget You" sign, plus the Turkish and the Israeli flags, welcome those arriving in the village. Turkish public opinion - surprisingly, Muslim press included - went out of its way to acclaim the Israeli support, rescue teams, humanitarian help, etc. Inevitably, a comparison was made between the Israeli rally to support Turkey and the help provided by Ankara's Arab neighbours; the end result was greatly in Israel's favour. It could be a mere coincidence but the "earthquake diplomacy" of Jerusalem and Athens symbolized a clear improvement in the bilateral relations of Greece and Israel with Turkey. The Turkish-Israeli volume of trade for the year 2000 - civil items only, tourism excluded - has reached, for the first time, the 1 billion dollars, a jump of more than 22 percent; joint military cooperation rocketed by 40 percent in comparison with 1999.

A second issue that is still pending is the possible exportation of Turkish water to Israel, to the volume of 50 million cubic meters annually - 10 percent of Israel's water shortage and about 2.5 percent of the country's annual consumption. Ankara insists that water from the Euphrates river will not serve a future peace agreement between Syria and Israel. That is to say, Syrian yielding to Israel water from the Jordan river and the Sea of Galilee could not be met by a Turkish allocation of more water from the Euphrates river to Damascus. The development of the Euphrates basin - the river's water in particular - is at the center of Turkey's GAP project. However, Turkey could become the central component in the region if it would irrigate the drought-stricken Middle East. This it could do by selling the water from its rivers that currently empty into the Mediterranean. Various issues are involved in this: Israeli hesitation to be dependent on a foreign supplier as regards an existential commodity like water; Turkey's eagerness to balance its arms trade with Israel by exporting water to the latter ("water for tank upgrading"); the 150 million dollar specially built terminal at the Manavgat river mouth, $60 \mathrm{~km}$ east of the city of Antalya, which empties into the Mediterranean (the terminal that was to serve the tankers that would load the river's water stands idle, waiting for its Middle Eastern buyers); the competition with the plunging prices of water desalination (50 cents per cubic meter, less than half the price of imported Turkish water); the pressures emanating from the Israeli military, Israel's arms industry, the IAI and the Foreign Office, who strongly support a water deal with Turkey, even if it is economically more expensive than other water production options; and so on. In July 2002 the water deal was not yet been finalized, a fact that threatened to mar the bilateral relations. The low cost of desalinated seawater from the projects that Israel has initiated in 2001 (due to be operational by 2004), and the controversy over the transportation of the water50 cent for a cubic meter - brought the negotiations to a standstill. Ankara wants 
the buyer to pay for the transportation - transportation thus becoming another Turkish export item to Israel - in addition to water. Israel wants the supplier to cover transportation and to halve the cost of the water at the Manavgat terminal, currently standing at $12-18$ cents a cubic meter. A surprising Israeli offer - to pay Turkey a one-off compensation of 150 million dollars, equal to the cost of the Manavgat terminal, and to buy itself out from the whole deal, raised angry reactions in Turkey. "We are not in favor of 'baksheesh"” commented the Turkish negotiators. ${ }^{123}$

The third event, this time with more detrimental effects - though it seems that both sides do their utmost to limit the damage - are the repercussions of the Israeli-Palestinian conflict on the above described relations. Presumably it is not very comfortable to be defined as a friend of Israel when so much criticism is directed against it. Indeed, in the Arab world Turkey was labelled as a party to the axis of evil, together with the United States and Israel. Implications were not slow in coming: no less a person than Bulent Ecevit, the Turkish Prime Minister, defined Israel as committing genocide against the Palestinians, and the newspaper Safak talked of "Adolf Sharon." Demonstrations were held against the Israeli football star, Haim Revivo, of Fenerbahce, with banners saying (in English), "Revivo Go Home." Public opinion polls taken at the height of the Palestinian uprising in the summer of 2001 showed that 81 percent of the Turks see Israel as their fourth biggest enemy after Armenia, the Republic of Cyprus, and Greece. Alternatively, others differentiated between "Sharon and his government" and the Israeli people: "governments come and go, but the real friendship of the people stays." And in the Hurriyet more positive voices talked about the help Israel handed to Turkey following the earthquake of 1999 and in capturing Abdullah Ocalan, the PKK leader. "Have ever the Palestinians handed us such help?" asked the newspaper. Scheduled visits and joint military exercises were initially postponed but later held as planned, and Ariel Sharon paid a visit to Ecevit in August 2001. No contract was cancelled. On the contrary, a 668 million dollar tender was given in March 2002 to the Israeli military industries to upgrade 170 US- made M-60 A-1 Turkish tanks. Neither did the remark of Ecevit go unnoticed, surprisingly in Turkey itself: "people who live in glass houses should not throw stones," was the reaction of Mehmet Ali Birand, a well-known publicist. ${ }^{124}$

\section{Summary: "a drama over a drama”}

Motivated by Kemalist eagerness to overcome - perhaps even to disregard - the geopolitics of the Middle East in which it is located, Turkey spent many years knocking on Western doors, while simultaneously persisting in the refusal to take sides in regional conflicts, whether between Israelis and Arabs, or any other standoff. That is, seemingly, a thing of the past: the 1991 Gulf War was a watershed, marking the renewal of Turkey's involvement - a very cautious one, but very circumspect - henceforth in the Middle East. Turkey's relations with Israel, 
and the inevitably pro-Israel position that that relationship projects - whether it is so in fact, or merely interpreted as such by the various players - offer a further expression of Turkey's growing involvement in the Middle East. This renewed interest in the Middle East, and Turkey's repeated rejection and attraction by the West and Europe (culminating in the 1997 and 1999 Luxembourg and Helsinki contradictory decisions), provide the context wherein Turkey's interaction with Israel has been molded in recent years. If membership of the Baghdad Pact in the 1950s was a fleeting episode which Ankara swiftly abandoned, the Gulf War and the relationship with Israel indicate that Turkey's involvement with the Middle East has now taken on facets of greater permanence.

Israel and Turkey have been motivated to weave their close ties by mutual interests, some of them existential. The region's two most pro-Western states whose democratic, and pro-American character and, equally, their usefulness to Western ends, have been placed in doubt since the termination of the cold war - collaborate with each other so as to survive as free societies. With US encouragement, Israel aids Turkey with arms and equipment denied by an indifferent Europe and hostile American public opinion. Turkey's air space, its ports, and other installations are made available to Israel. Israeli training facilities are available to Turkey. Neither Turkey nor Israel expects the other country to fight its wars. It may be just as well: in spite of Turkey's membership of NATO, Ankara has often wondered whether other members of the alliance would hasten to its defence if called upon to do so. The vigour radiated by the links between the two states, and the American support they enjoy - Ankara and Israel welcome even a greater American role in the region - apparently exude a tone of status quo over the region. Revisionist players who plan to upset that status quo might be reluctant to put the alliance to the test.

The economic and civil contacts element underlies the military ties between Turkey and Israel. It renders their interaction more permanent, as a structure whose components have an interest in its survival over time. The middle class and elite in both countries have mutual trade contacts. Many, as a result, have vested interests in their survival and development. Incidentally, while the elite in the Arab world boycott Israel, the Turkish elite is at the forefront of contacts with it. One could therefore safely say that the rapprochement clearly consists of both peoples, not only their governments. If this collaboration possesses strategic dimensions, it is precisely the non-military links between Ankara and Jerusalem that support them. To sustain this, one should bear in mind that, more than between any two Middle Eastern countries, bilateral Turkish-Israeli trade (military and tourism excluded) is the highest in the region. Joint ventures the two countries have initiated in Central Asia, in commercial fields as in production and delivery of energy, development of water sources, development of all kinds of terra incognita, etc., all feature a strategic dimension, not necessarily of guns and tanks. On the contrary, the non-military aspects give a wide basis to the relationship, probably projecting longevity. By way of comparison, all other bilateral special relations of Israel (with France, Iran and South Africa) that 
failed were principally of one dimension - the military or governmental one and lacked a wide basis.

The culmination of any political relationship is a mutual exposure to the culture and society of the people behind it. One can safely conclude that Turks and Israelis are on the right path toward this kind of exposure. "A drama over a drama," is the definition given by Alon Liel, the Israeli Chargé d'Affairs in Ankara in the early 1980s, to the current Turkish-Israeli economic, political, military, cultural and social rapprochement. Dr Liel's impressions should be taken seriously: in the early 1980s, when Turkey downgraded its relations with Israel, it enabled merely a representation of junior diplomats. Liel was then the junior Israeli representative in Ankara. When it comes to evaluating the current rapprochement, "a drama over a drama" is the right definition for the comparison between the 1980 s and the 1990s and the early years of the twenty-first century.

\section{Notes}

1 David Ben Gurion complained of Turkey's refusal to acknowledge its ties with Israel, comparing it to the way a man relates to his mistress. Quoted in Amikam Nachmani, Israel, Turkey and Greece: Uneasy Relations in the East Mediterranean, London, Frank Cass, 1987, p. 75.

2 Uri Gordon, "Israel-Turkey Relations: From Legation to Embassy," Israel Turkey Trade, Tel-Aviv, a publication of the Israel Turkey Business Council, No. 6, 2000.

3 See Engin Erdem, Bibliography on Turkish-Israeli Relations, 16 January 2002, http://tsi.idc.ac.il/Bibliography.html; Ofra Bengio and Gencer Ozcan, "Old Grievances, New Fears: Arab Perceptions of Turkey and its Alignment with Israel," Middle Eastern Studies, Vol. 37, No. 2, April 2001, p. 69. See also Raphael Israeli, "The Turkish-Israeli Odd Couple," Orbis, Vol. 45, No. 1, Winter 2001, pp. 65-79; William Safire, New York Times, reprinted in Ha'aretz, 7 February 1999; Amnon Barzilai, Ha'aretz, 4 July 2001; Anat Lewin, "Turkey and Israel: Reciprocal and Mutual Imagery in the Media, 1994-1999," Journal of International Affairs, Vol. 54, No. 1, Autumn 2000, p. 240.

4 Sabah, 7 September 1998.

5 Peres to Hikmet Cetin, Speaker of the Turkish Grand National Assembly, Yeni Yuzyil, 10 March 1999. For the "sandwich" view see Ergun Balci, Cumhuriyet, 3 November 1998; Al-Quds, 8 September 1998; Hurriyet, 9 September 1998; Zaman, 10 September 1998.

6 Alon Liel, Ha'aretz, 22 December 1997. See also the comments of Zeev Schiff, one of Israel's leading military commentators: "The impression nowadays is that imprudent P.R. sometimes motivates Israeli-Turkish relations ... There is talk of the necessity of preserving confidentiality, but everything is swiftly leaked. And the media cannot be held to blame. It's not so much the media calves that want to suck, as the establishment cow wants to give suckle with scoops about the Israeli-Turkish flirtation. It happens in both camps." Ha'aretz, 2 January 1998.

7 Washington Post, 23 December 1997.

8 Maurice Fisher, Israeli Legation, Ankara, to Foreign Ministry, 19 January 1954. Quoted in Nachmani, Israel, Turkey and Greece, pp. 62-63. During the 1950s, Solel-Boneh - one of Israel's largest construction corporations - built airfields in Turkey.

9 Aksiyon Magazine, 18-24 May 1996. The agreement is signed by General Cevik Bir, the Turkish Deputy Chief-of-Staff, and David Ivry, the General Director of the Israeli Defence Ministry. 
10 Ha'aretz, 27 May 1997.

11 Ha'aretz, 26 May 1996.

12 On the Israeli support to the Kurdish struggle see, Shlomo Nakdimon, A Hopeless Hope: The Rise and Fall of the Israeli Kurdish Alliance, 1963-1975. Tel Aviv, Miskal-Yediot Ahronot Books and Chemed Books, 1996; Milliyet, 18 March 1999.

13 Ergun Balci, Cumhuriyet, 3 November 1998; interviews, Ankara, February-June 1999; M. Necati Ozfatura, Turkiye, 9 October 1998; Mensur Akgun, Yeni Yuzyil, 11 October 1998.

14 Ha'aretz, 12 April 1996.

15 Ha'aretz, 8 December 1997.

16 Yediot Ahronot, 7 January 1997.

17 Ha'aretz, 19 October 1997.

18 Ha'aretz, 20 January 1998.

19 Athens News Agency, DNB, 14 November 1996; "Greece's Armed Forces Modernize," COSMOS, Athens Institute of International Affairs, Panteion University, Vol. 2, No. 1, May-June 1997. The Greek media mentioned Israel as a possible supplier of the following arms: 250 new tanks valued at 400 million dollars; anti-aircraft missiles - 300 million; unmanned aircraft (drones) - 20 million; early warning aircraft -500 million; communications equipment -8 million; and three missile boats. See Ha'aretz, 5 October 1997.

20 Ha'aretz, 29 January 1997; 5 and 27 October 1997; DNB, 21 October 1996.

21 Sema Emiroglu, quoting Turkish Foreign Minister Ismail Cem, Milliyet, 17 September 1998.

22 Ceyda Karan, Radikal, 28 December 1998. The Palestinian PEN Club invited Karan to visit the Palestinian Authority and Israel, and she authored a series of articles entitled, "Palestine on the Way to Independence."

23 Mehmet Dikbayir, "Cold Shower to the Arabs," Turkiye, 5 May 1999.

24 Ceyda Karan, Radikal, 28 December 1998.

25 Faruk Caliskan, Radikal, 21 June 1998.

26 Ceyda Karan, Radikal, 29 December 1998.

27 Ha'aretz, 30 September 1997.

28 Ha'aretz, 23 November 2000.

29 Cumhuriyet, 5 November 1994.

30 Guneri Civaoglu, "Unsuccessful Arafatization," Milliyet, 3 December 1998.

31 Ali Bulac, Zaman, 14 January 1999.

32 Akit, 21 September 1997.

33 Sabah, 24 September 1997.

34 Nazif Okumus, Yeni Gunaydin, 18 September 1997.

35 Ha'aretz, 28 and 31 August 1997.

36 Yediot Ahronot, 12 May 2000; Sabah, 11 May 2000.

37 Lili Galili, Ha'aretz, 25 April 2000.

38 Ibid.

39 Tom Segev, Ha'aretz, 28 April 2000.

40 Ha'aretz, editorial, 27 April 2000.

41 Guntay Simsek, Zaman, 18 June 1998.

42 Selin Caglayan has written for Yeni Yuzyil; Abdulkerim Balci for Zaman; Vahap Yazaroglu for Milliyet.

43 Yeni Yuzyil, 7 June 1999; Hurriyet, 27 February 1999; Turkiye, 8 June 1999; Sabah, 1 June 1998; Hurriyet, 17 June 1998; Radikal, 17 June 1999; Milliyet, 6 January 1999; Milliyet, 18 March 1999; Yeni Yuzyil, 14 August 1998; Milliyet, 18 August 1998; Zaman, 1 August 1998.

44 Guntay Simsek, Zaman, 22 June 1998; Aydin Engin, Cumhuriyet, 8-10 January 1999. 
45 Guntay Simsek, Zaman, 22 June 1998.

46 Faruk Caliskan, Radikal, 21 June 1998; Milliyet, 7 June 1998.

47 Aydin Engin, Cumhuriyet, 8-10 January 1999.

48 Taha Kivanc (alias Fehmi Koru), Zaman, 9 September 1998. Kivanc was in a group of journalists who followed Prime Minister Yilmaz on his visit to Jordan and Israel.

49 Israel Harel, Ha'aretz, 29 November 1998; Steff Wertheimer, Ha'aretz, 12 February 1999; Yigal Tomarkin, Ha'aretz, 1 June 1999. Note the titles of the articles: "Talk to Him in Turkish," "Aren't There Anymore Civilians in this Country," "Turkey, for Example," respectively. See also Ha'aretz, 3 November 2000.

50 Israel Goodovitch, Chairperson, The Israeli Association of Architects and City Engineers, Ha'aretz, 30 May 2001.

51 Ilhan Selcuk, Cumhuriyet, 10 July 1997. Emphasis added. See also Mehmet Ali Kisalali, Turkiye, 7 June 1998, interview with Professor Hasan Koni.

52 Ha'aretz, 30 September 1997.

53 See, for instance, Fikret Ertan, Zaman, 17 January 1999; Sabah, 18 January 1999.

54 Sabah, Zeynep Gogus, 20 February 1999; Turkiye, Vakur Kaya, 22 February 1999.

55 Barry Jacobs, Assistant Director, Office of Government and International Affairs, the American Jewish Committee, "The Role of the American Jewish Committee in Fostering Relations and as a Friend of Turkey," lecture, Istanbul, the Marmara Hotel, 9-10 June 1999; TDN, 29 July 1999; Daniel Mariaschin, Director, the B'nai B'rith International Center for Public Policy, interview, TDN, 28 July 1999. In November 1998 the Jewish American organizations placed a full-page advertisement in major international newspapers, congratulating Turkey on its seventy-fifth anniversary. It started: "Congratulations! Mazeltov! Tebrikler!" See copy in TDN, 29 July 1999.

56 Ha'aretz, 8 December 1997.

57 Erdal Guven, Radikal, 13 September 1998.

58 Ha'aretz military commentator Zeev Schiff posed the following question and answer in Ha'aretz, 2 January 1998: Why does the Chinese Foreign Minister, during his visit to Cairo, permit himself to bypass Israel and criticize the Israeli-Turkish-American naval exercise to be held next week? What is the difference between this minor exercise - dealing with search and rescue - and the [joint] maneuvres of the Egyptian and Saudi navies, or the maneuvres the Egyptian army holds with American forces? [China has numerous confidential deals with Israel, but] one gets the impression that, whenever it touches upon Israel, states permit themselves to say things they hesitated to voice before Netanyahu's elevation to office. The ties between Israel and Turkey are an illustration thereof.

59 Philip Robins notes that the agreements for military cooperation between Israel and Turkey were signed when there was no government in Turkey, i.e. during the transition between the December 1995 elections and the formation of the new government in 1996. See Philip Robins, “Turkish Foreign Policy under Erbakan,” Survival, Vol. 39, No. 2, Summer 1997, p. 83.

60 With the aim of containing the Islamic religious trend in the Turkish school system, the army chiefs instructed Erbakan to close the religious Imam Hatip Lycees, in existence in Turkey since 1951, and extend compulsory education from five to eight years (even without the legal extension, most of the 15 million students attending state schools stay on for eight years). On terminating the five years' study prescribed by the compulsory education law, 500,000 pupils resume their studies at some 600 religious schools for an additional three- to seven-year period. The religious schools were founded originally for the purpose of training imams for the mosques, but the current numbers of graduates exceed the needs of the country's religious establishment. Each year, diplomas qualifying them as religious preachers are issued to 53,000 graduates, though only 2,300 are required. The following figures relate to the Imam Hatip Lycees and their students (it is 
interesting to note that Erbakan's term of office was the only period with no increase in the number of schools): 1951, 7 schools; 1975, less than 150,000 pupils; 1992, 389 schools; 1995, 479,000 pupils at 448 schools; 1996, 493,000 pupils at 561 schools. See The Economist, reprinted in Ha'aretz, 19 December 1996; Ha'aretz, 29 April 1997, 17 and 20 August 1997; Time, 12 January 1998.

61 See also Daniel Pipes, “The Birth of a New Middle East Alliance. Turkey and Israel's Brilliant Joint Move,” Washington Times, 5 January 1998. In December 1996, Sincan mayor, Bekir Yildiz, proclaimed a municipal ban on the sale of turkeys for the upcoming New Year celebrations. New Year, Yildiz declared, is a Christian festivity, and Turks should not mark it by eating turkey; furthermore, just as markets were barred from selling sheep for slaughter for the Muslim Feast of Sacrifice, sales of turkeys would likewise be banned. See DNB, 23 December 1996.

62 Ha'aretz, 19 May 1996; 30 September 1997.

63 Yeni Safak, 12 May 1997.

64 Ibid., 13 May 1997; Milliyet, 10 September 1998; Cumhuriyet, 17 December 1998; M. Necati Ozfatura, Turkiye, 17 December 1998; M. Necati Ozfatura, Turkiye, 27 May 1999; Muhsin Eminzadegh, Deputy Foreign Minister of Iran, interviewed by Selcuk Gultasli and Kemal Ilter, Zaman, 6 February 1999.

65 Milli Gazete, 14 May 1997.

66 Yeni Safak, 14 May 1997.

67 Akit, 14 May 1997.

68 Yeni Safak, 12 May 1997; M. Necati Ozfatura, Turkiye, 27 April 1999.

69 Aydin Menderes, Yeni Safak, 12 May 1997. Aydin's father, Adnan Menderes, was Turkey's Prime Minister, 1950-60. He was toppled in the 1960 military coup, charged with corruption, and executed by hanging in 1961 .

70 Aydin Menderes, Yeni Safak, 8 May 1997.

71 Sabah, 1 November 1995.

72 Ha'aretz, 30 September 1997; George E. Gruen, “Turkish-Israeli Relations: Crisis or Continued Cooperation," Jerusalem Letter, Jerusalem Center for Public Affairs, No. 338, 13 July 1996.

73 Yeni Safak, 8 May 1997.

74 Yediot Ahronot, 30 September 1997.

75 Yeni Gunaydin, 18 September 1997.

76 Ha'aretz, 20 November 1996.

77 See a call for a Marshall Plan to add the "sane" countries - Turkey, Jordan, Israel, Ha'aretz, 8 April 2002.

78 Yediot Ahronot, 18 October 1996.

79 Jordan, a silent partner to some of the Turkish-Israeli strategic interaction, expressed its wish to increase its share in this cooperation. Amman is reluctant to be a "spare tyre" for these bilateral relations wrote Sabah, 4 September 1998. See also Ha'aretz, 18 April 2000; Turkish Probe, a weekly publication of the TDN, 14 February 1999; TDN, 16 April 1999; Efraim Inbar, The Israeli-Turkish Entente, London, King's College Mediterranean Studies, 2001, pp. 57-59.

80 Ha'aretz, 28 April 2000.

81 The Turks are to pay Israel 5 percent interest on the plane modernization, whereas contracts with other parties prescribe interest payments of 30 percent - ostensibly because of the high risk of default. During the first two years of the project, the company carrying out the upgrading is to get paid by the Israeli government in the form of a loan from Israel's finance ministry to its Turkish counterpart. Modernization of the F-4s is to cost some 800 million dollars. Modernization of the F-5s costs 75 million. Work on modernization will take two to three years. See Ha'aretz, 9 August 1996; Ha'aretz, 8 December 1996; Ha'aretz, 1 January 1998; Cumhuriyet, 31 July 1996. 
82 Yeni Safak, 3 September; Yeni Safak, 10 December 1996; Ha'aretz, 7 April 1996; Ha'aretz, 9 August 1996; Ha'aretz, 9 November 2001.

83 A seemingly precise text of the agreement appeared in the Turkish Aksiyon Magazine, 18-24 May 1996. The agreement was initially made public in the winter of 1996, though various drafts of it had been signed as early as March 1994, as the Aksiyon publication revealed.

84 Ha'aretz, 17 April 1996; 1 January 1998; 3 June 2001; Jerusalem Post, 11 February 2002. An irony is linked to the 1990s Israeli airforce overt presence in Turkey: On 6 September 1980, Necmettin Erbakan's National Salvation Party organized in Konya the Jerusalem Liberation Day Rally. Many observers believe that the event was the final incident that prompted the Turkish military to seize power and perform the coup d'état of $12 \mathrm{Sep}$ tember 1980. In the rally, the demonstrators called for the restoration of the Caliphate, refused to sing the Turkish national anthem, carried anti-Semitic signs and burned the Israeli, American and Russian flags - flags of "Two Great Satans and one Little Satan." Less than a week later, the military seized power, abolished the existing parties and arrested Erbakan and other leaders. See George E. Gruen, "Defining Limits on Religious Expression in Public Institutions: The Turkish Dilemma," paper prepared for the Jerusalem Center for Public Affairs Summer workshop, 1998, pp. 23-24.

85 Ha'aretz, 3 and 6 June 2001.

86 Ha'aretz, 15 and 19 October 1997; 8 December 1997; 2 January 1998; 10 May 1999; 31 July 2001; TDN quoted in Ha'aretz, 13 May 1997. According to TDN, Turkey and Israel would jointly manufacture Popeye missiles to a value of 500 million dollars, by means of Turkey's Mike company, and the Israeli Rafael. The first missiles are to be delivered to Turkey during the coming two and a half years. In the short term, Israel is to deliver Popeye missiles to meet Turkey's urgent needs. It was reported further that the Popeye would also be installed in Turkish F-4s being upgraded in Israel. Ha'aretz, 10 May 1999, reported a tough, even ugly, competition among the Ehud system manufacturers. At the end the IAI won the tender.

88 Ha'aretz, 8 December 1997; 8 January 1998; 28 April 2000; 14 August 2001; 29 August 2001; Inbar, The Israeli-Turkish Entente, p. 22.

89 Ha'aretz, 2 May 2001; 16 May 2001; 14 August 2001; 2 April 2002.

90 The Economist, "Survey Turkey," 8 June 1996; TDN, reprinted in Ha'aretz, 17 September 1996; Ha'aretz, 10 March 1997; DNB, 9 April, 5 August 1996.

91 The Israeli Manufacturers' Association sets Israeli civilian exports to Turkey to the value of 600 million dollars annually. This is 15 percent of potential Turkish imports from Israel, estimated to reach 4 billion dollars. See Israeli Manufacturers' Association, Department for Foreign Trade and International Relations, Considerations in Creating an Israeli-Turkish Free Trade Zone Tel Aviv, August 1993, Hebrew, pages unnumbered.

92 Zaman, 31 October 1996.

93 DNB, 9 December 1996.

94 Ha'aretz, 30 March 1997; 5 July 1999; 30 November 1999; 28 May 2002; Israeli Manufacturers' Association, Considerations in Creating an Israeli-Turkish Free Trade Zone. To cut labour wages the IDF closed its sewing workshops for bullet-proof jackets and moved them to Turkey, Ha'aretz, 31 July 2001.

95 Israeli Manufacturers' Association, Considerations in Creating an Israeli-Turkish Free Trade Zone.

96 Ha'aretz, 23 June 1997; 24 November 1999 (the figures were given by Israel's Lottery Authority). The number of Turkish tourists visiting Israel is small: 1995, 11,767; 1996, 14,341; 1997, 19,000 (estimated).

97 For the cultural exchanges see, TDN, SPECIAL, 21 April 1999; Guneri Civaoglu, Milliyet, 20 December 1998; Ha'aretz, 13 February 2002.

98 Ayse Ellegard, Radikal, 15-18 August 1998. 
99 Ibid.

100 "Help from a Friend," Sabah, 9 October 1998; Vahap Yazaroglu, Milliyet, 9 October 1998. Sukru Kucuksahin, Hurriyet, 17 November 1998, report of a speech Prime Minister Yilmaz gave the day before at the ANAP party council. Yilmaz praised the Iraqi Kurdish leader, Barazani, and the Israeli Mossad, for furnishing Turkey with much valuable information pertaining to the whereabouts in Syria of Abdullah Ocalan.

101 Lale Sariibrahimoglu, Cumhuriyet, 16 December 1998; Vahap Yazaroglu, Milliyet, 30 April 1999.

102 Taha Kivanc alias Fehmi Koru, Zaman, 9 September 1998.

103 Bengio and Ozcan, “Old Grievances, New Fears," p. 66.

104 Philip Robins, Turkey and the Middle East, London, Royal Institute of International Affairs and Pinter Publishers, 1991, pp. 49, 50; Ihsan Gurkan, "Turkish-Israeli Relations and the Middle East Peace Process," Turkish Review of Middle East Studies, Vol. 7, 1993, p. 109; Cumhuriyet, 27 October 1998; Hurriyet, 27 October 1998; Bengio and Ozcan, “Old Grievances, New Fears," p. 66.

105 Paul Rivlin, Israeli-Turkish Economic Relations, Tel Aviv University, The Dayan Center, 11 December 1997, Table 4.

106 TDN reprinted in Ha'aretz, 4 July 1997.

107 Bengio and Ozcan, “Old Grievances, New Fears," p. 63.

108 Al'Qusbou Al'Arabi, Beirut, weekly, 15 April 1997.

109 Al'Siasa Al'Dowliah, Cairo, quarterly, July 1997.

110 Stephen J. Blank, “The Eastern Question Revived: Russia and Turkey Contend for Eurasia," paper submitted to the conference on Muslim Republics of the Former Soviet Union, Tel Aviv University, 12-14 October 1993, p. 25.

111 Major General David Ivry, who negotiated on behalf of Israel the military agreements with Turkey, interview, Milliyet, 8-9 Novemeber 1998.

112 Ilhan Selcuk, Cumhuriyet, 23 February 1999.

113 Ofra Bengio, Tel Aviv University, The Dayan Center, 11 December 1997.

114 Al'Mshahid Al'Siasi, London, weekly, 12-18 May 1996; Al'Watan Al'Arabi, Paris, weekly, 17 May 1996.

115 Khaled bin Sutlan bin Abed al-Aziz, TDN, reprinted in Ha'aretz, 4 July 1997. His reference to Eritrea's anti-Arab policy relates to that country's conquest of the island of Hanish from Yemen.

116 Ibid.

117 On Arab claims against the Ottomans see Bengio and Ozcan, "Old Grievances, New Fears," pp. 52-54.

118 Khaled bin Sutlan bin Abed al-Aziz, TDN, reprinted in Ha'aretz, 4 July 1997.

119 Ha'aretz, 28 July 1997.

120 Ha'aretz, 17 September 1997.

121 Robins, “Turkish Foreign Policy under Erbakan,” pp. 90-91; Cumhuriyet, 23 September 1997.

122 Ha'aretz, 6 August 2001.

123 Baksheesh was rampant in the Ottoman Empire and is roughly equal to bribe.

124 Ha'aretz, 7 April 2002; Yediot Ahronot, 19 April 2002; Cumhuriyet, 7 April 2002; Fahmi Howeidi, Ashraq al-Awsat, reprinted in Mideast Mirror, 21 August 2001. 